\title{
Searching for Clarity Amid Confusion: An Examination of the Standards for Determining Waiver and Revival of the Right to Arbitrate
}

\author{
By John Bruce Lewis* and Dustin M. Dow**
}

\section{INTRODUCTION}

A hallmark of the American precedent-based legal system is consistency. From jurisdiction to jurisdiction, state court to federal court, legal doctrines built upon the foundation of historic precedent are generally applied with uniform - or at least recognizably similar-rules and guidelines, leading to predictable results. ${ }^{1}$ That is, unless the subject is waiver of arbitration rights.

Under what circumstances does a party involved in litigation waive the right to enforce a valid arbitration agreement? Why does it —or should it - matter if the plaintiff asserts class-action claims? And what may prompt a court to revive previously waived arbitral rights? Those three questions at the heart of this article are seemingly straightforward. But the answers to them are anything but.

In the United States, arbitration is increasingly used to resolve disputes in many diverse areas, including those involving consumer, commercial, anti-trust, securities, foreign investments and employment law. ${ }^{2}$ This

*Partner, Baker \& Hostetler, LLP, Cleveland, Ohio. B.A., J.D., University of Missouri-Columbia; LL.M., Columbia University.

**Associate, Baker \& Hostetler, LLP, Cleveland, Ohio. B.S., Kent State University; J.D. Boston College Law School.

The authors wish to thank Caitlin Grimes, Carrie Valdez and Alyssa Daniels for their valuable assistance during the preparation of this article.

1. See, e.g., Phillip J. Closius, Rejecting the Fruits of Action: The Regeneration of the Waste Land's Legal System, 71 Notre DAME L. ReV. 127, 130 (1995) ("The modern stare decisis system is designed to produce a consistency of result and a similar outcome in fact patterns that are identical or nearly so.").

2. See generally BG Group PLC v. Republic of Arg., 572 U.S. 25 (2014) (dispute under international treaty); Stolt-Nielsen S.A. v. AnimalFeeds Int'l Corp., 559 U.S. 662 (2010) (antitrust dispute); Circuit City Stores, Inc. v. Adams, 532 U.S. 105 (2001) (applying FAA to employment contract); Mitsubishi Motors Corp. v. Soler Chrysler-Plymouth, Inc., 473 U.S. 614 (1985) (international sales agreement and antitrust dispute); Scherk v. Alberto-Culver Co., 417 U.S. 506 (1974) (Securities Exchange Act of 1934 violation); see also WILliam W. PARK, ARBITRATION OF INTERNATIONAL BUSINESS DISPUTES 701-02 (2d ed. 2012) (describing foreign investment 
growth was fueled in part by U.S. Supreme Court decisions beginning in 1983 that amplified the scope and impact of the Federal Arbitration Act (FAA). ${ }^{3}$ The expanded use of arbitration agreements ${ }^{4}$ has also created new

arbitration).

3. See, e.g., Kindred Nursing Ctrs. Ltd. P'ship v. Clark, 137 S. Ct. 1421, 1426-27 (2017) (rejecting state rule that subjected the formation of arbitration agreements to a higher standard as inconsistent with the FAA); DIRECTV, Inc. v. Imburgia, 136 S. Ct. 463, 471 (2015) (“[California's interpretation] does not give 'due regard . . . to the federal policy favoring arbitration.' Thus, the Court of Appeal's interpretation is pre-empted by the Federal Arbitration Act." (citation omitted) (quoting Volt Info. Scis., Inc. v. Bd. of Trs. of Leland Stanford Junior Univ., 489 U.S. 468, 476 (1989))); AT\&T Mobility LLC v. Concepcion, 563 U.S. 333 (2011) (finding that the application of state unconscionability principles to arbitration clauses waiving class action was invalidated by the FAA); Gilmer v. Interstate/Johnson Lane Corp., 500 U.S. 20 (1991) (holding an Age Discrimination in Employment Act claim can be subjected to compulsory arbitration under the FAA); Shearson/Am. Express, Inc. v. McMahon, 482 U.S. 220 (1987) (permitting arbitration of claims under the Racketeer Influenced and Corrupt Organizations Act); Mitsubishi, 473 U.S. 614 (enforcing an arbitration agreement concerning claims under the Sherman Act); Moses H. Cone Mem'l Hosp. v. Mercury Constr. Corp., 460 U.S. 1, 24 (1983) ("Section 2 [of the FAA] is a congressional declaration of a liberal federal policy favoring arbitration agreements, notwithstanding any state substantive or procedural policies to the contrary.").

4. Some members of the media, academics and judges disagree concerning the proper scope and interpretation of the FAA, particularly in the employment and consumer law areas. See S. 2838, The Fairness in Nursing Home Arbitration Act: J. Hearing on S. 2838 Before the Subcomm. on Antitrust, Competition Policy \& Consumer Rights of the S. Comm. on the Judiciary \& the Spec. Comm. on Aging, 110th Cong. 12-17 (2008) (statement of Stephen Ware, Professor, University of Kansas School of Law) (opposing a bill banning pre-dispute arbitration agreements for nursing home residents); Christopher R. Drahozal, "Unfair” Arbitration Clauses, 2001 U. ILl. L. REV. 695, 696700 (2001) (describing critiques of arbitration); Peter B. Rutledge \& Christopher R. Drahozal, "Sticky" Arbitration Clauses? The Use of Arbitration Clauses After Concepcion and Amex, 67 VAND. L. REV. 955, 955-65 (2014) (examining the extent to which companies have included arbitral class waivers in consumer contracts following two Supreme Court cases permitting these waivers); Jean R. Sternlight, Disarming Employees: How American Employers Are Using Mandatory Arbitration to Deprive Workers of Legal Protection, 80 BROOK. L. REV. 1309, 1317-22 (2015) (describing Supreme Court decisions expanding use of arbitration agreements in employment settings and predicting employers will rely on these decisions to defeat employee class actions); Jessica Silver-Greenberg \& Robert Gebeloff, Arbitration Everywhere, Stacking the Deck of Justice, N.Y. TIMES (Oct. 31, 2015), https://www.nytimes.com/2015/11/01/business/dealbook/arbitration-everywhere-stacking-the-deckof-justice.html [https://perma.cc/7G3J-C6BT]; Jessica Silver-Greenberg \& Michael Corkery, Efforts to Rein In Arbitration Come Under Well-Financed Attack, N.Y. TiMES (Nov. 15, 2015), https://www.nytimes.com/2015/11/16/business/dealbook/efforts-to-rein-in-arbitration-come-underwell-financed-attack.html [https://perma.cc/B42U-8GAE]; Jessica Silver-Greenberg \& Michael Corkery, In Arbitration, a 'Privatization of the Justice System', N.Y. TIMES (Nov. 1, 2015), https://www.nytimes.com/2015/11/02/business/dealbook/in-arbitration-a-privatization-of-the-justicesystem.html [https://perma.cc/3H8P-R2J3]; Jessica Silver-Greenberg \& Michael Corkery, Rule on Arbitration Would Restore Right to Sue Banks, N.Y. TIMES (May 5, 2016), https://www.nytimes.com/2016/05/05/business/dealbook/consumer-agency-moves-to-assert-bankcustomers-right-to-sue.html [https://perma.cc/F28Q-UMR2]; Jed S. Rakoff, Why You Won't Get Your Day in Court, N.Y. REV. OF BOOKS (Nov. 24, 2016), https://www.nybooks.com/articles/2016/ 11/24/why-you-wont-get-your-day-in-court/ [https://perma.cc/9FYH-QNGC]; Anonymous, Opinion, Washington's Arbitration Deception, WALL ST. J. (May 17, 2016, 7:09 PM), https://www.wsj.com/ articles/washingtons-arbitration-deception-1463526580 [https://perma.cc/T9CE-MMYU]. Much of the disagreement seems to stem from differing understandings of the genesis of the FAA, its purpose, and from related policy concerns regarding the impact of arbitration versus litigation on the parties. 
situations in which parties may be found to have waived their arbitral rights. Moreover, the increased frequency of class and other aggregate litigation has created issues involving arbitration agreements and the rights of putative class members. As Supreme Court decisions continue to shape the contours of arbitral rights, the circumstances of waiver correspondingly evolve with the availability of arbitration and the use of class-action waivers. ${ }^{5}$

Waiver, which we explore in depth below, generally occurs when a party voluntarily and knowingly relinquishes a right. But, in litigation involving contractual arbitration provisions, assessing waiver typically involves an examination of the extent to which a party, by pursuing or defending a court action, acted inconsistently with its right to arbitrate. And, the existence of prejudice to the opposing party may also be a decisive factor. ${ }^{6}$

An important side-effect of the shifting waiver landscape is the opportunity for revival of the right to arbitrate following certain circumstances of waiver. For many decades courts have grappled with when a party has waived or was "in default" of its right to arbitrate. ${ }^{7}$

But the enforceability of a contract is not static. Whether in alimony, real estate, or any number of other settings, changed circumstances or changed conditions may necessitate a fresh review of the scope of contractual rights and whether a previously waived right has been revived. Increasingly, the same is true in arbitration. In fact, arbitration agreements are not mere contracts. They are agreements that are supported by the policy flowing from the FAA, favoring resolution of disputes through arbitration. ${ }^{8}$ Increasingly, courts rely on that policy to revive the right to

5. See cases cited supra note 3 and infra note 283.

6. See Thomas J. Lilly, Jr., Participation in Litigation as a Waiver of the Contractual Right to Arbitrate: Toward a Unified Theory, 92 NEB. L. REV. 86, 100-12 (2013) (discussing different factors and approaches the courts of appeals use to determine whether a party has waived its right to arbitration).

7. See Kahnweiler v. Phenix Ins. Co. of Brooklyn, 67 F. 483 (8th Cir. 1895) (holding that by filing suit instead of submitting dispute to arbitrators, as contemplated by the insurance contract, the parties waived their right to arbitration). After passage of the FAA some courts referred to the Act's "default" language in $\S 3$. A default was generally viewed by the courts as a waiver. See, e.g., Middlesex Cty. v. Gevyn Constr. Corp., 450 F.2d 53, 56 n.2 (1st Cir. 1971) (referring to the "default" provision of 9 U.S.C. § 3); Robert Lawrence Co. v. Devonshire Fabrics, Inc., 271 F.2d 402, 412 (2d Cir. 1959) ("Lawrence asserts that Devonshire has waived its right to arbitrate or was 'in default in proceeding with such arbitration' under Section 3 of the Act."); Am. Locomotive Co. v. Chem. Research Corp., 171 F.2d 115, 121 (6th Cir. 1948) ("“T]he delay on appellant's part in moving for a stay was unreasonable and unexcusable under all the circumstances and constituted 'default' on its part in proceeding with the arbitration.").

8. See Moses H. Cone Mem'l Hosp., 460 U.S. at 24-25 ("The Arbitration Act establishes that, as a matter of federal law, any doubts concerning the scope of arbitrable issues should be resolved in 
arbitrate a claim even where waiver might have previously made arbitration unavailable.

There was a time when the prevailing notion was that "[o]nce the right to arbitrate a particular dispute has been lost by an election to litigate it [could not] be recaptured." " But that paradigm has shifted through threeplus decades and with marked frequency in the past several years. No longer does a party to an arbitration agreement waive its enforcement once and for all by participating in litigation for a certain period. A burgeoning body of case law, emphasizing the fairness of waiver, futility, aggregate action complications and revival, reflects that in any given case, waiver may be a nuanced conclusion that can change over time. After all, when litigation takes an unforeseen left turn, "fairness dictates that a defendant's prior waiver of arbitration be nullified and the right to compel arbitration revived." 10

In this article, we explore the developing body of waiver and revival case law to outline its contours, which hinge, in part, on notions of fairness to each party with respect to the arbitration agreement. In Part II, we briefly review the murky history of arbitral waiver-when and why it occurs. Part III examines the varying standards governing waiver throughout the country, detailing the different approaches to waiver that affect arbitral rights by jurisdiction. Part III also examines the application of the waiver doctrine in aggregate litigation. Indeed, the right to arbitrate claims in the class action context, and the extent to which that right has been waived or not, is particularly complex and subject to different approaches in different jurisdictions. No area deserves clear, meaningful standards more than in dealing with waiver issues in the class action environment. Yet, what exists is disturbing ambiguity. A party may not realize that an arbitration right is waived until a court says so. And that finding could have disastrous economic consequences.

This background is essential to understanding the components of a revived arbitral right, or when courts have found no original waiver as to a particular claim due to the futility of originally seeking arbitration or because of the class action context of a case. We explore these multifaceted issues in Part IV. There, we analyze the cases that have

favor of arbitration ....”); Republic Ins. Co. v. PAICO Receivables, LLC, 383 F.3d 341, 344 (5th Cir. 2004) (noting a "strong presumption against finding a waiver of arbitration" (citing Subway Equip. Leasing Corp. v. Forte, 169 F.3d 324, 326 (5th Cir. 1999))).

9. Sherrill v. Grayco Builders, Inc., 475 N.E.2d 772, 777 (N.Y. 1985).

10. Plaintiff's Shareholders Corp. v. S. Farm Bureau Life Ins. Co., 486 F. App'x 786, 790 (11th Cir. 2012); see also Krinsk v. SunTrust Banks, Inc., 654 F.3d 1194, 1202 (11th Cir. 2011) (“[A] defendant's waiver of the right to compel arbitration is not automatically nullified by the plaintiff's filing of an amended complaint" (citing Gilmore v. Shearson/Am. Express Inc., 811 F.2d 108, 112 (2d Cir. 1987))). 
accepted or rejected the existence of revival and isolate the relevant details that inform the results. Following in Part V, we provide our conclusion on the general state of waiver and revival law and its impact on the resolution of claims in many areas of law. We also explain the significance of the futility and revival doctrines where uncertainty underlies the potential enforcement of certain arbitration agreements specifically in class or aggregate action settings.

\section{History OF ARBITRATION BEGINS WITH THE WAIVER}

\section{A. The Foundation of the Waiver Doctrine}

The history of waiver, of course, begins with an understanding of the history of arbitration, which reaches further back than the origins of the English common law, ${ }^{11}$ with roots that can be traced to Roman and Canon law. ${ }^{12}$ Arbitration generally enjoyed widespread use and favorable treatment in early English common law for several reasons, including the

11. Martin Domke et AL., DOMKe on COMmercial ARbitration § 2.1-2.3 (2016) (discussing the origins of arbitration and its use in ancient Greece and Rome); Julius Henry Cohen \& Kenneth Dayton, The New Federal Arbitration Law, 12 VA. L. REV. 265, 266 (1926) ("The use of arbitration dates back to the earliest days of which we have historical knowledge. It furnished almost exclusively the tribunals for the settlement of business disputes in the medieval period, and in England up to Lord Mansfield's day was practically the sole remedy open to English merchants.").

12. Peter J. Smith IV, Investors Win: Howsam v. Dean Witter Reynolds, Inc. Makes Entering Arbitration Quicker, Easier, and Less Expensive, 4 PEPP. DiSP. RESOL. L.J. 127, 128 (2003). The use of arbitration was prevalent in English religious guilds with early records indicating these guilds had codified arbitration agreements by at least 1388. DereK Roebuck, Mediation and ARBItRation IN THE MIDDLE AGES: ENGLAND 1154-1558 220-21 (2013) (describing a writ issued by Richard II of England in 1388 requiring religious guilds to submit a copy of their rules). Evidence exists that Merchant and craft guilds similarly codified arbitration provisions by 1348. Id. at 226-27 (noting a 1348 ordinance of the Oxford Barbers guild requiring members to submit disputes to the guild for resolution). See also William C. Jones, An Inquiry Into The History Of The Adjudication Of Mercantile Disputes In Great Britain And The United States, 25 U. CHI. L. REV. 445, 447-50 (1958) (discussing the establishment of separate mercantile tribunals in England as early as 1100). Arbitration was also used to settle disputes within religious groups, including the Jewish community in England and the Christian church. RoEBUCK, supra at 235, 286. Women also played a role in early English arbitration, though female arbitrators were rare and of high rank. Id. at 275-77. History shows widespread use and codification of arbitration in the 1100s. Arbitration in England included instances both where parties freely elected to use arbitration and where the court ordered parties into arbitration. See generally id. at 53-65 (discussing court-ordered arbitration as well as the parties' ability to submit their disputes to arbitration); James Oldham, The Historically Shifting Sands of Reasons to Arbitrate, 2016 J. DisP. RESOL. 41, 41 (2016) (describing the opportunity to select an arbitrator and the confidentiality of arbitration as aspects of the practice); Margo Todd, 'For Eschewing of Trouble and Exorbitant Expense': Arbitration in the Early Modern British Isles, 2016 J. DISP. RESOL. 7, 16 (2016) ("[J]udges in all kinds of courts were by all accounts happy to refer cases to arbitrators ...."); but see Paul L. Sayre, Development of Commercial Arbitration Law, 37 YALE L.J. 595, 598 (1928) ("[I]n the early common law, arbitration was entirely a matter of private arrangement for which there was no authority except the personal authority of the parties to the agreement ...."). 
economic benefits of arbitration, ${ }^{13}$ expertise brought by arbitrators, ${ }^{14}$ and the business or trade knowledge that arbitrators could bring that would be beyond the realm of litigation. ${ }^{15}$

Yet, many believe that in the 1600s, the English courts' attitude shifted, essentially becoming hostile. ${ }^{16}$ This shift has been attributed to Lord Coke's 1609 decision in Vynior's Case, which has been called "the original and controling [sic] authority for revocability" of arbitration agreements. ${ }^{17}$ Due to Lord Coke's apparent distaste for arbitration

13. Oldham, supra note 12 , at $42-43$; Smith, supra note 12 , at 128 (noting that courts were slow and therefore expensive); Todd, supra note 12, at 9-10.

14. Cohen \& Dayton, supra note 11, at 278 ("Before Lord Mansfield's day the courts of England were ignorant of the manner in which they should treat questions respecting the buying and selling of goods or marine insurance or promissory notes, or, indeed, any mercantile question."); Bruce H. Mann, The Formalization of Informal Law: Arbitration Before the American Revolution, 59 N.Y.U. L. REv. 443, 470 (1984); Oldham, supra note 12, at 48-53; Smith, supra note 12, at 128 (noting merchants and guilds believed courts lacked adequate knowledge of trade disputes).

15. Mann, supra note 14, at 454-55 (describing how arbitrators in colonial Connecticut were often from the same town as the disputants, unlike jurors who were selected on a colony-wide basis, and therefore could craft solutions so the parties could continue to live civilly in the same community); Todd, supra note 12, at 8 (noting that arbitrators, who were selected from the local community, often knew the parties involved, the history of the disagreement, and could address the origins of a dispute); see also James Oldham, ENGLish COMmon LAw In The AGe Of MANSField 69 (Thomas A. Green et al. eds., 2004) ("There are over three hundred cases in Lord Mansfield's trial notes that were referred to arbitration in lieu of a jury verdict."); JAMES OLDHAM, THE MANSFIELD MANUSCRIPTS AND THE GROWTH OF ENGLISH LAW IN THE EIGHTEENTH CENTURY 152 \& nn.403-05, app. E (Thomas A. Green ed., 1992) (first listing the names of a few arbitrators, their occupations, and the cases they arbitrated, and then collecting Lord Mansfield's cases from 1756-1786 in which arbitrators were used and listing the names and occupations of those arbitrators); Jones, supra note 12, at 456 ("Another indication of the popularity of arbitration is the inclusion of forms for arbitration agreements and awards in form books and manuals designed for tradesmen and their clerks."); Oldham, supra note 12, at 42 ("Arbitrament is much esteemed and greatly favoured in our Common Law ... to prevent the great Trouble and frequent Expense of Law-suits." (quoting AUTHOR OF REGULA PlaCiTANDI, ARBITRIUM REDIVIVUM: OR THE LAW OF ARBITRATION (London, Isaac Cleeve 1694)).

16. DOMKE, supra note 11 , at $\S 2.5$ \& n.4; Wesley A. Sturges \& Irving Olds Murphy, Some Confusing Matters Relating to Arbitration Under the United States Arbitration Act, 17 LAW \& CONTEMP. PROBS. 580, 582-83 (1952) ("[I]n a case like this, involving the [FAA], we should not follow English or other decisions which have narrowly construed the terms of arbitration agreements or arbitration statutes." (quoting Kulukundis Shipping Co. v. Amtorg Trading Corp., 126 F.2d 978, 985 (2d Cir. 1942))).

17. Sayre, supra note 12, at 602; but see Philip G. Phillips, A General Introduction, 83 U. PA. L. REV. 119, 123-24 (1934) (questioning Vynior's impact on business behavior); Sayre, supra note 12, at 601-02 (noting judges did not immediately come to rely on Vynior's Case for upholding the revocability of arbitration agreements); Todd, supra note 12, at 16-17 ("Since [English] judges in all kinds of courts were by all accounts happy to refer cases to arbitrators, what happened in the early modern period to lead later students of dispute resolution to the quite false presumption that arbitration was always extra-judicial, and that the courts were enemies of the process? The culprit seems to be a misunderstanding of Robert Vynior's case, an action brought to the Court of Common Pleas in 1609 against William Wilde for his failure to pay a bond of $£ 20$ ordered by arbitrators to resolve a dispute over 'divers kinds of parish business.' . . . Many modern jurists seem to consider this case as the legal origin of non-binding arbitration; they apparently see common law courts as jealous of the alternative path to resolution. Coke, however, needs to be read with more attention to his own historical 
agreements which ousted the courts, ${ }^{18}$ judicial hostility towards arbitration is said to stem from "the perception that the agreements allowed parties to circumvent the court's jurisdiction." 19

Early American colonists brought from England the practices of mediation and arbitration to resolve disputes. ${ }^{20}$ Consequently, arbitration was commonly used throughout early America. ${ }^{21}$ However, as the common law developed in the United States, the "jealousy of the... courts for their own jurisdiction" increased. ${ }^{22}$ Following what they understood as English precedent, American courts were reluctant to lend their authority to the enforcement of arbitration agreements. ${ }^{23}$ To combat this hostility and the presumption of revocability - where either party could withdraw from an arbitration agreement at any time without the fear of damages ${ }^{24}$-New York passed the New York Arbitration Act of $1920 .^{25}$

context."); Earl S. Wolaver, The Historical Background of Commercial Arbitration, 83 U. PA. L. REV. 132, 138-44 (1934) (analyzing the reasoning of Vynior's Case, arguing it was correctly decided based on the case's specific facts and applicable law, and describing subsequent English cases expanding the revocability of arbitration agreements).

18. DOMKE, supra note 11 , at $\S 2.5$.

19. Id. at $\S 6.1$.

20. Derek Roebuck, The English Inheritance-What the First American Colonists Knew of Mediation and Arbitration, 2016 J. DisP. RESOL. 325, 328-29 (2016) ("Th[e] exportation [of mediation to early America] included not only the practice of mediation and arbitration to resolve disputes, but also the high value placed on those dispute resolution processes by individuals and entities as varied as individual colonists and the Privy Council.”); see also Jones, supra note 12, at 460 ("[Colonial] merchants used at one time or another every type of court available in the colony to settle their disputes, and from time to time they devised new forms for their own use. ... The New York Merchants also used private voluntary arbitration."); Mann, supra note 14, at 447 ("Along with other legal traditions, arbitration was part of the cultural baggage of the trans-Atlantic migration.").

21. Mann, supra note 14, at 452 (colonial Connecticut and Massachusetts); Roebuck, supra note 20, at 347 (noting an early Maryland arbitration case).

22. Smith, supra note 12, at 130 (quoting H.R. REP. No. 68-96, at 1 (1924)).

23. Cohen \& Dayton, supra note 11, at 283 ("For many centuries there has been established a rule, rooted originally in the jealousy of courts for their jurisdiction, that parties might not, by their agreement, oust the jurisdiction of the courts. This rule was so firmly established that our American courts did not feel themselves free to change the rule, but declared it to be the duty of the legislature to make this change.").

24. Smith, supra note 12, at 129.

25. Section 1448 of the New York Civil Practice Act provided that the contract "shall be valid, enforceable and irrevocable, save upon such grounds as exist at law or in equity for the revocation of any contract." N.Y. Civ. Prac. Act. § 1448. It has since been replaced by N.Y. C.P.L.R. 7501 (McKinney 2013). For a comparison of the language of the 1920 New York Arbitration Act to various contemporaneous state arbitration acts, see WeSLEY A. STURGES, A TREATISE ON COMMERCiAL ARBITRATIONS AND AWARDS $§ 27$ (1930). The New York City Chamber of Commerce played a large role in the passage of the New York Arbitration Act and later the Federal Arbitration Act (FAA). Amalia D. Kessler, Arbitration and Americanization: The Paternalism of Progressive Procedural Reform, 124 YALE L.J. 2940, 2943, 2949-50 (2015) (discussing the role and motives of various groups interested in procedural reform that led to the New York act, but noting that both acts "were the product of a massive educational and lobbying campaign that was initiated by ... [the] head of the New York Chamber of Commerce's Committee on Arbitration" who later joined forces with the New York Bar 
This legislation sought to "avoid the procedural intricacies ... of ... litigation" while promoting "a commercially reasonable and knowledgeable dispute resolution process." ${ }^{26}$ In other words, businesses could rely on the arbitration agreements they executed.

The contractual nature of arbitration agreements played a prominent role in the early waiver cases, but equitable considerations lurked in the background. The initial focus on contract law and the underlying circumstances is perhaps best reflected in the 1933 Second Circuit case Krauss Bros. Lumber Co. v. Louis Bossert \& Sons, Inc. ${ }^{27}$ A brief explanation of the procedural details in Krauss illustrates the complex considerations in play regarding waiver. In Krauss, the merchant parties initially orally agreed to the sale of thousands of feet of small timbers. ${ }^{28}$ In an "Order Acknowledgement," the plaintiff seller detailed the terms of the sale and included an arbitration clause. ${ }^{29}$ The Order added that unless the defendant buyer notified the plaintiff seller to the contrary, it was final and binding. ${ }^{30}$ The defendant buyer did not object and accepted the timber delivery. ${ }^{31}$ After the defendant buyer failed to pay, the plaintiff seller sued in state court for the purchase price. ${ }^{32}$ The defendant buyer filed an answer, a counterclaim and also raised the arbitration clause. ${ }^{33}$ The plaintiff seller replied to the counterclaim, and both parties served notice of trial. ${ }^{34}$ After unsuccessfully moving for voluntary dismissal, the plaintiff seller sent defendant a letter accepting the defendant buyer's offer to arbitrate as pled in the answer. ${ }^{35}$ The defendant buyer refused to arbitrate and the plaintiff seller instituted an action in federal court to enforce the arbitral agreement. The district court compelled arbitration,

\footnotetext{
Association's Committee on the Prevention of Unnecessary Litigation); see also Carbonneau, supra note 21, at 245 (noting the relationship between New York's Arbitration Act and the FAA).

26. Carbonneau, supra note 21, at $245 \mathrm{n} .47$ (citing Thomas E. Carbonneau, The Reception of Arbitration in United States Law, 40 ME. L. Rev. 263, 268 (1988)); see also Hiro N. Aragaki, Constructions of Arbitration's Informalism: Autonomy, Efficiency, and Justice, 2016 J. DISP. RESOL. 141, 147 (2016) ("In the decades leading up to the enactment of the FAA, the courts were widely perceived as unable to deliver substantial justice. Crippling delays and mounting backlogs made it difficult for claims to be adjudicated on their merits in a timely fashion. Even when they were, the resulting decision according to the law often did not reflect the layperson's sense of what was right." (footnotes omitted)).

27. 62 F.2d 1004 (2d Cir. 1933)

28. Id. at 1005 .

29. Id.

30. Id.

31. Id.

32. Id.

33. Id.

34. Id.

35. Id.
} 
and the defendant buyer appealed, ${ }^{36}$ arguing that the plaintiff seller had forfeited arbitration by bringing an action in state court. ${ }^{37}$

In analyzing the circumstances in which a party forfeits its right to enforce an arbitration agreement, Judge Learned Hand noted that "[t]he question [of waiver] is one of contract only, for the [FAA] does not impose any condition upon the remedy, presupposing that it merely enforces the promise to submit controversies to arbitration." 38 If the court sought only to consider the nature of the offer and acceptance under contract law, the analysis would have ended when Judge Hand found that the defendant "could not prevent the plaintiff's resumption of the remedy, while its own position remained unchanged." ${ }^{39}$ But while the Second Circuit characterized waiver as a question of contract only, the court nevertheless recognized that the "rights of the parties are measured by equitable considerations, [which] prevent a party from playing fast and loose with his adversary." 40 Furthermore, the Second Circuit demonstrated its reluctance to find waiver based solely on participation in the litigation under the FAA, relying on a defendant's willingness to submit to arbitration, as demonstrated through its answer and moving affidavits, as sufficient to retain the right to arbitrate. ${ }^{41}$

Some commentators rely on the contractually-based language of early

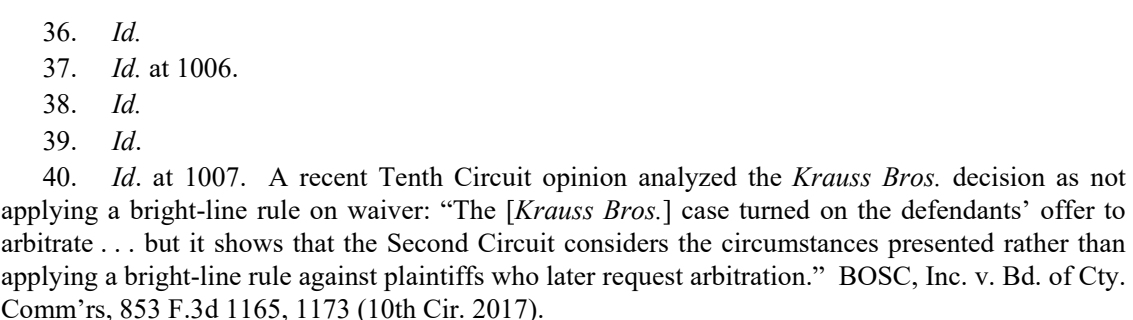

41. Krauss Bros. Lumber Co., 62 F.2d at 1006-07; see also Shanferoke Coal \& Supply Corp. v. Westchester Serv. Corp., 70 F.2d 297, 299 (2d Cir. 1934) (defendant not in 'default' when in its answer and moving affidavits it expressed its "willingness to submit to arbitration"), aff'd on other grounds, 293 U.S. 449 (1935). The court also applied equitable considerations in The Belize v. Steamship Owners Operating Co., 25 F. Supp. 663 (S.D.N.Y. 1938). There, plaintiff sued defendant for allegedly damaging a vessel owned by the plaintiff. $I d$. at 664 . The defendant submitted an answer and did not invoke the arbitration clause that existed in the parties' underlying contract. The defendant also submitted interrogatories to which the plaintiff responded. Later, the plaintiff moved to stay the proceedings and sought to enforce the arbitration agreement. In denying plaintiff's motion, the court acknowledged that the arbitration clause was binding and enforceable on both the plaintiff and defendant, and that the parties waived arbitration by their conduct. Id. The court remarked: "This conclusion is unavoidable on the law of contracts. It is also supported by practical consideration." Id. The court concluded that "there comes a time in the course of the litigation when it would be unfair to permit one side to resort to arbitration over the protest of the other. That time is reached when the defendant files an answer on the merits, joining with the plaintiff in rejecting arbitration and tendering the controversy to the court for trial." Id. In The Belize, the court used contractual principles to inform its conclusion but also considered fairness to the parties. 
judicial opinions to maintain that waiver decisions were entirely premised on contract principles. ${ }^{42}$ Courts, however, also used the rubric of contract law to structure their equitable analyses. In the arbitration context, courts have found that waiver occurs when the plaintiff brings a claim and the defendant participates in the litigation. ${ }^{43}$ Early courts were quick to state that they were relying on contractual principles to determine whether a party had waived its right to arbitrate. Yet, the analysis rarely ended with understanding whether there was offer and acceptance to waive the arbitration agreements; courts frequently considered equitable type issues such as delay and the impact of conduct on adversaries in conjunction with their contractual analysis. ${ }^{44}$

Prior to formalized arbitration law, some of the earliest cases involving the agreement to arbitrate did appear to rest on contractual principles. For example, in People v. Court of Common Pleas, Onondaga ${ }^{45}$ the Supreme Court of Judicature of New York denied defendant's motion for mandamus in which defendant sought to set aside a verdict favoring plaintiff in a slander suit. ${ }^{46}$ Defendant sought that result because the case had initially been submitted to arbitration and litigation was discontinued. ${ }^{47}$ However, arbitration never resolved the issue because one of the arbitrators could not attend. ${ }^{48}$ The court ultimately found that the defendant had waived the right to arbitrate "by the defendent's [sic] counsel appearing on the trial, cross-examining the plaintiff's witnesses, and addressing the jury." ${ }^{49}$ So, not unexpectedly, participation on behalf of the defendant in trial was sufficient to constitute waiver. ${ }^{50}$ This

42. For a discussion of the waiver approaches, see Robert B. Martin, Waiver of the Right to Compel Arbitration-A Directional Analysis, 16 CAL. W. L. REV. 375, 388-94 (1980).

43. Krauss Bros. Lumber Co., 62 F.2d at 1006 ("The state action was indeed a repudiation of the plaintiff's own promise to arbitrate; it gave the defendant an election ... to put an end to the arbitration clause . . . By its plea in the answer it chose [to arbitrate]." (citing Hosiery Mfrs.' Corp. v. Goldston, 143 N.E. 779 (N.Y. 1924))); Zimmerman v. Cohen, 139 N.E. 764, 765 (N.Y. 1923) ("[T]he plaintiffs made their election [to settle their disputes through litigation instead of arbitration] when they brought their action against the defendant ignoring the agreement to arbitrate. The defendant made his election when he answered . . ..").

44. See, e.g., Radiator Specialty Co. v. Cannon Mills, Inc., 97 F.2d 318, 319 (4th Cir. 1938) (holding the defendant waived its right to arbitration by waiting to assert that right until the day of the trial); Krauss Bros. Lumber Co., 62 F.2d at 1006; The Belize, 25 F. Supp. at 664; In re Bauer Co. v. Anderson Chem. Co., 206 A.D. 423, 426 (N.Y. App. Div. 1923) (finding waiver when the defendant waited three years after filing a complaint and notice of trial before seeking to compel arbitration).

45. 1 Wend. 314 (N.Y. Sup. Ct. 1828).

46. Id. at $314-15$.

47. Id. at 314.

48. Id.

49. Id. at 315 .

50. Similarly, in Laflin v. Chicago, W. \& N. Railway Co., 34 F. 859 (C.C.E.D. Wis. 1887), the Circuit Court for the Eastern District of Wisconsin held the presence of an arbitration agreement did 
rationale was extended in Harrison v. German-American Fire Insurance $C{ }^{51}$ where a federal court held that " $[\mathrm{t}]$ here must be . . . no action which is inconsistent with the right to rigidly insist on an award" taken by the defendant, "else that right is waived." 52

But the threshold focus on contract appears to have shifted in Kahnweiler v. Phenix Insurance Co. of Brooklyn. ${ }^{53}$ The court in Kahnweiler addressed the fairness of the pleadings on both parties when discussing the contract containing the arbitration agreement, finding that "when a defendant relies upon a breach of a condition precedent ... he must set out specifically the condition and the breach, so that the plaintiff and the court will be advised of the issue to be tried." ${ }^{54}$ In finding that the defendant waived the right to demand arbitration, the court applied such equitable considerations as the expense and delay that failure to detail the breach of condition precedent would entail. ${ }^{55}$

Equitable considerations continued to be the basis of the New York

not preclude litigation, and, alternatively, the parties waived their right to arbitrate. In Laflin, the defendant constructed a railroad in close proximity to plaintiff's hotel. Id. at 859 . Plaintiff sued alleging that defendant's railroad would have an injurious effect upon plaintiff's hotel business. Id. Subsequent to the commencement of the lawsuit, the parties entered into an agreement to arbitrate. $I d$. at 859-60. On appeal, the court held that the mere making of an agreement to submit a controversy to arbitration does not absolutely discontinue any pending suit. $I d$. at 864 . The court further reasoned that even if its conclusion was wrong, the "discontinuance has been waived by the acts and conduct of the defendant in proceeding to a trial of the case and contesting it upon the merits." Id. And in Chamberlin v. Hibbard, 38 P. 437 (Or. 1894), the court found waiver when a party's answer did not request enforcement of an arbitration agreement. Chamberlin involved a construction contract dispute. Id. at 437 . The parties entered into a construction agreement which provided that if any dispute arose involving the value of completed work, the parties would submit the dispute to an umpire, whose decision would be binding on the parties. Id. at 438. After the defendant allegedly defaulted on the amount due, the plaintiff instituted a foreclosure action. Id. at 437 . The plaintiff did not attach a copy of the original contract to his complaint. $I d$. at 438 . While the defendant included a copy of the contract in his answer, he failed to plead its arbitration provision. Id. The Oregon Supreme Court found that defendant waived his right to have an arbitrator value the completed work by pleading to the merits in his answer and not raising the arbitration provisions. Id.

51. 67 F. 577 (C.C.S.D. Iowa 1895).

52. Id. at 582. Harrison also discusses condition precedent, which is outside the scope of this article.

53. 67 F. 483 (8th Cir. 1895).

54. Id. at 485; see also W. Assurance Co. of Toronto v. Decker, 98 F. 381, 383 (8th Cir. 1899) (finding that if neither party demands arbitration, they have both waived it (quoting Kahnweiler, $67 \mathrm{~F}$. at 488)).

55. Kahnweiler, 67 F. at 486-87 ("By failing to set [forth the arbitration requirement] and its breach in its answer, the defendant waived that defense. If the rule were otherwise, a degree of uncertainty would be introduced in the practice in this class of cases much greater even than that which obtained under the general issue at common law. It would be a snare and a pitfall, and neither the plaintiff nor the court would have any knowledge of the issue to be tried."); see also Hiltl Co. v. Bischoff, 198 N.Y.S. 915 (N.Y. App. Div. 1923) (mem.) (reversing lower court and finding no waiver before trial where defendant served an answer containing a counterclaim and the case was noticed for trial). 
high court's waiver decisions, as illustrated by Hosiery Manufacturers' Corp. v. Goldston. ${ }^{56}$ The Hosiery court affirmed the reversal of the trial court, which previously held that the defendant waived its right to arbitrate merely by filing its answer. ${ }^{57}$ In concluding there was no waiver, the court acknowledged that although the defendant participated in the litigation to some extent by filing an answer, it did not waive the right to arbitrate because it asserted that right in its answer. ${ }^{58}$ The court also underscored the equitable principles embraced by New York's Arbitration Law by comparing it to the English Arbitration Act. The court noted that while the English Act contained a limitation under which a party must invoke the right to arbitrate before delivering a pleading, the New York Arbitration Law contained no similar limitation. ${ }^{59}$

After Congress enacted the FAA, federal courts were prompted to consider the question of waiver. Initially, "early commentaries and decisions under the Act assumed that no equitable discretion could be exercised" so courts "engaged in strained and technical interpretations of the clauses before them."60 Because the FAA was based largely on the New York Arbitration Law, many aspects of the common law waiver doctrine developed under the New York Act initially influenced the federal courts' reasoning. ${ }^{61}$ In the 1930 s, courts began to turn to principles of equity to support their findings. ${ }^{62}$

As the case law developed, the interconnected relationship between

56. 143 N.E. 779 (N.Y. 1924); see also Nagy v. Arcas Brass \& Iron Co., 150 N.E. 614, 614 (N.Y. 1926) (per curiam) ("[U]nreasonable delay in making the proper application may justify a finding of waiver" because New York's "Arbitration Law contemplates prompt action, and too long a delay in seeking appropriate relief may be easily construed as an indication that this claim is waived.").

57. Hosiery, 143 N.E. at 780.

58. Id.; but see The Belize v. Steamship Owners Operating Co., 25 F. Supp. 663, 664 (S.D.N.Y. 1938) ("The libellant in its libel tried to reserve the right to resort to arbitration at a later time. The attempted reservation was futile... . But where there is knowledge of the necessary facts on which to found a choice of inconsistent remedies, an asserted reservation of the right to take the inconsistent remedy later on is of no avail." (citation omitted)).

59. Hosiery, 143 N.E. at 780.

60. Comment, Judicial Exercise of Equitable Discretion in Enforcement of Arbitration Contracts, 21 U. CHI. L. REv. 719, 721 (1954). For example, in Young v. Crescent Development Co., 148 N.E. 510, 510-11 (N.Y. 1925), the court determined that a dispute arising from the nonperformance of a contract did not fall under the contract, so the arbitration clause did not apply.

61. See Alessandra Rose Johnson, Note, Oh, Won't you Stay with Me?: Determining Whether $\S$ 3 of the FAA Requires a Stay in Light of Katz v. Cellco Partnership, 84 FordHAm L. Rev. 2261, 2266 (2016) (noting that since the FAA mirrors the New York Act in some respects, New York decisions interpreting the state law are at the very least persuasive).

62. Comment, Judicial Exercise of Equitable Discretion in Enforcement of Arbitration Contracts, supra note 60, at 721 ("In the 1930's, however, the federal courts began turning to principles of equity to achieve their results, and highly technical grounds for refusing enforcement were not so often relied upon."). 
equitable and contract principles continued to evolve. In Almacenes Fernandez, S. A. v. Golodetz, ${ }^{63}$ plaintiffs brought suit alleging that containers used in shipping caustic soda were "dented, rusted and unfit for shipment," leading to damages. ${ }^{64}$ In its answer, Golodetz denied most of the allegations in the complaint and set forth a counterclaim asserting the arbitration agreement. ${ }^{65}$ Within six months, Golodetz "caused seven third party defendants to be joined" in the action. ${ }^{66}$ At the end of that six-month period, Golodetz "moved for an order staying the action" and requiring arbitration. ${ }^{67}$ In considering whether Golodetz waived its right to arbitrate, the court noted that where a defendant asserts a counterclaim on the merits, "[its] conduct in so doing may amount to a waiver which will bind them both." ${ }^{68}$ However, even waiting several months (or until the eve of trial) before requesting arbitration does not divest a party of that right as "the trial judge has discretion to deny the application of a party thus in default." ${ }^{69}$ Even so, "delay in moving for an arbitration order will not alone amount to a default." 70

The history of the waiver of arbitration agreements does not present a singular or easily articulated standard to determine when a party waived

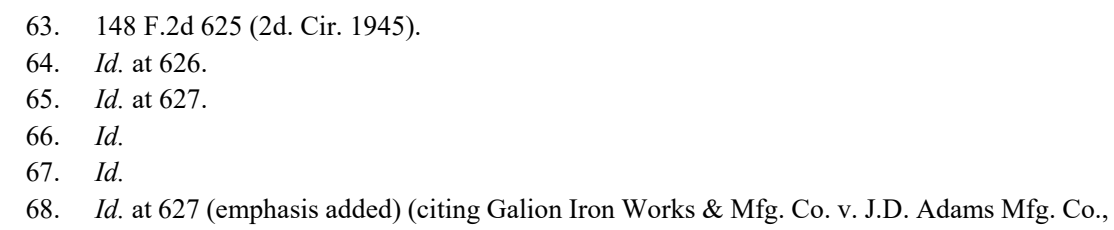
128 F.2d 411 (7th Cir. 1942)). In Galion, the court determined that plaintiff, in electing to pursue litigation, had waived its right to submit to arbitration under the contract; when defendant submitted an answer on the merits, it also waived its right to submit to arbitration. 128 F.2d at 413. See also La Nacional Platanera, S.C.L. v. N. Am. Fruit \& S.S. Corp., 84 F.2d 881, 883 (5th Cir. 1936) (“Under a reasonable construction of [the FAA] the District Court was vested with discretion to deny the prayer for the reference of the dispute to arbitrators as well as to refuse to stay the suit if he considered plaintiff was in default in proceeding with the arbitration. We have no hesitancy in deciding that by bringing the action at law to recover damages, ignoring the provisions of the charter party for arbitration, and then delaying for nearly four years before attempting to invoke arbitration, plaintiff was so much in default that he was not entitled to demand arbitration.").

69. Almacenes Fernandez, S. A., 148 F.2d at 627 (citing Radiator Specialty Co. v. Cannon Mills, Inc., 97 F.2d 318 (4th Cir. 1938)). In Cannon Mills, where a stay of the trial was sought by defendant under the FAA, the court stated "[t]he trial judge is vested with discretion to refuse to stay the action if he is of the opinion that the party seeking arbitration is in default." 97 F.2d at 318-19. The court ultimately found " $[\mathrm{b}] \mathrm{y}$ setting up a counterclaim for damages the defendant ... expressly invoked" the court's jurisdiction. Id. at 319. Moreover, "[t]he cases relied upon on behalf of the defendant are all cases in which there was no dilatoriness or unexplained delay on the part of the party seeking arbitration." Id. at 320

70. Almacenes Fernandez, S. A., 148 F.2d at 628; see also Kulukundis Shipping Co. v. Amtorg Trading Corp., 126 F.2d 978, 980, 989 (2d Cir. 1942) (holding that a defendant who had waited to assert his right to arbitrate until nine months after the lawsuit was initiated had not waived that right because "no important intervening steps had been taken in the suit and no one had been affected by the delay"). 
the right to arbitrate. But a common thread running through the early cases suggests an interplay of equitable and contractual considerations. While many of the cases discussed contractual aspects of waiver-such as the election, or offer, that one party makes to litigate, rather than arbitrate, and the election of the other party, or acceptance of that offer-the legal analysis went further to consider the equity of finding waiver at that point in the proceedings, often looking to expense, delay, or prejudice. In that respect, the considerations laid down by the early cases are still reflected in today's disparate waiver standards.

\section{B. What Has Changed in the Legal Environment?}

The legal environment has changed considerably since the elements of waiver were first contemplated. That change has given rise to many of the issues with which modern courts must now contend. Indeed, early decisions involving arbitration were not required to confront many of the "revival" issues currently based on the amendment of complaints or classrelated waiver problems. There are several possible explanations for this absence.

First, amending complaints to add claims or expand damages was difficult before 1938. The Federal Rules of Civil Procedure were adopted in $1938 .^{71}$ The rules brought the right to liberally amend pleadings, which did not previously exist. ${ }^{72}$

Second, modern Rule 23 class actions did not exist until $1966 .{ }^{73}$

71. Jack B. Weinstein, After Fifty Years of the Federal Rules of Civil Procedure: Are the Barriers to Justice Being Raised?, 137 U. PA. L. REV. 1901, 1901 (1989).

72. See generally Supreme Court Adopts Rules for Civil Procedure in Federal District Courts, 24 A.B.A. J. 97 (1938) (describing the history of the Federal Rules of Civil Procedure and the Rules Enabling Act); Weinstein, supra note 71, at 1906, 1913-17 (discussing the underlying ethos of the rules and commenting on proposed amendments).

73. Eisen v. Carlisle \& Jacquelin, 41 F.R.D. 147, 148 (S.D.N.Y. 1966), rev'd on other grounds, 391 F.2d 555 (2d Cir. 1968) (stating the effective date of Rule 23 was July 1, 1966). See 28 U.S.C. App. § IV, r. 23 (1964 \& Supp. II); David Marcus, The History of the Modern Class Action, Part I: Sturm Und Drang, 1953-1980, 90 WASH. U. L. REV. 587, 588, 603-09 (2013) (describing the drafting history of Rule 23 and how subsequent events set the stage for an expansive use of the rule); Brian T. Fitzpatrick, The Ironic History of Rule 23 2-4 (Vanderbilt Law Sch. Legal Studies Research Paper Series, Working Paper No. 17-41, 2017), https://papers.ssrn.com/sol3/papers.cfm?abstract_id $=3020306$ [https://perma.cc/P2X6-FDDU] (discussing how Rule 23's class action mechanics could encompass a much larger class of plaintiffs and, contrary to the 1938 version of the provision, adopted an opt-out provision). Much of the recent increase in federal court class actions may be due to the passage of the Class Action Fairness Act of 2005 (CAFA), which made removal of class actions to federal court substantially easier for class defendants. See, e.g., Howard M. Erichson, CAFA's Impact on Class Action Lawyers, 156 U. PA. L. REV. 1593, 1610 (2008) ("CAFA has increased not only the number of class action removals to federal court, but also the number of class action original filings in federal court."); Gail E. Lees et al., Year in Review on Class Actions: 2011 a Blockbuster Year for 
number of the waiver and "revival" decisions involve class actions filed after that date or the court's jurisdiction over putative class members. ${ }^{74}$

Third, collective wage and hour actions did not exist until 1938 and were not in their present form until 1947. On June 25, 1938, President Franklin Roosevelt signed the Fair Labor Standards Act (FLSA), which became effective October 24, 1938. ${ }^{75}$ Congress amended Section 16(b) of the FLSA in 1947 in response to a wave of wage and hour representative litigation in the manufacturing sector. ${ }^{76}$ With the amendments, "the representative action by plaintiffs not themselves possessing claims was abolished, and the requirement that an employee file a written consent [the opt-in request] was added." 77 Despite the 1947 amendments, FLSA collective actions now are one of the more frequently filed types of employment-related aggregate litigation claims in the U.S. ${ }^{78}$

Fourth, U.S. Supreme Court decisions have driven many of the revival or "futility" decisions discussed in this article. Supreme Court decisions such as Shearson/American Express, Inc. v. McMahon (agreements to arbitrate Securities Exchange Act claims enforceable under the FAA) ${ }^{79}$

Litigators, Highlighted by Supreme Court Rulings in Dukes and Concepcion, 13 Class Action Litig. Rep. (BNA) No. 4, at 225 (Feb. 24, 2012) (noting a "massive increase" in class action filings following CAFA, and that "[C]onsumer class action filings increased by $577 \%$ in the district courts in the Ninth Circuit!").

74. See discussion infra Sections III.C-D.

75. John S. Forsythe, Legislative History of the Fair Labor Standards Act, 6 LAW \& CONTEMP. Probs. 464, 473 (1939); Leah Avey, Note, Walk to the Line, Compensable Time: Cash in the Pockets of Employees, 32 OKLA. CiTY U. L. REV. 135, 137 (2007).

76. See, e.g., Integrity Staffing Solutions, Inc. v. Busk, 135 S. Ct. 513, 515-17 (2014) (discussing the circumstances surrounding the passage of the Portal-to-Portal Act of 1947); see also Hoffmann-La Roche Inc. v. Sperling, 493 U.S. 165, 173 (1989) (explaining that the amendment had "the purpose of limiting private FLSA plaintiffs to employees who asserted claims in their own right and freeing employers of the burden of representative actions" (citing various sections of the Portalto-Portal Act)); Unexcelled Chem. Corp. v. United States, 345 U.S. 59, 62 n.1 (1953) (explaining that the amendments reflected a Congressional view that the FLSA had "been interpreted judicially in disregard of long-established customs, practices, and contracts between employers and employees, thereby creating wholly unexpected liabilities" (quoting the Portal-to-Portal Act $\S 1$ (a), 29 U.S.C. $\S$ 251(a) (2012))).

77. Hoffmann-La Roche, 493 U.S. at 173 (citing 93 Cong. Rec. 538, 2182 (1947) (remarks of Sen. Donnell regarding the Portal-to-Portal Act of 1947)). The Act amended section 16(b) of the FLSA to include "No employee shall be a party plaintiff to any such action unless he gives his consent in writing to become such a party and such consent is filed in the court in which such action is brought." Portal-to-Portal Act of 1947, Pub. L. No. 49, § 5(a), 61 Stat. 84, 87-88 (1947) (codified as amended at 29 U.S.C. § 216) (West, Westlaw through Pub. L. No. 115-231).

78. See Robert Teachout, Fewer Wage and Hour Class Actions Filed, But Value of Settlements Spikes, SOC'Y FOR Hum. RESOURCE MGMT. (Feb. 7, 2017), https://www.shrm.org/resourcesand tools/legal-and-compliance/employment-law/pages/class-action-wage-and-hour-2016.aspx [https:// perma.cc/P8GH-BG6L] (citing the results of the Seyfarth Shaw 2016 annual report, which attributes the popularity of filing wage and hour cases to the relatively low cost to justify class certification).

79. 482 U.S. 220 (1987). 
and AT\&T Mobility LLC v. Concepcion (class action waivers within arbitration provisions subject to the FAA are enforceable) ${ }^{80}$ were catalysts for change. These decisions overruled or revised earlier Supreme Court or state court precedent that placed restrictions on arbitration, belatedly enabling some cases to be resolved by arbitration.

Finally, the impact of the "prejudice" requirement for waiver or to defeat revival after a change in law, regardless of how long the case may have been pending in court, has led to further judicial scrutiny and analysis. ${ }^{81}$ Irrespective of the cause, courts are now confronted with more waiver, futility and revival issues than in the first 50 years of the FAA.

\section{THE STANDARDS FOR WAIVER DIFFER SUBSTANTIALLY BY JURISDICTION.}

As its history reflects, the waiver doctrine in arbitration is neither uniform in application nor connected in linear fashion. The absence of a single test for waiver has led to a variety of standards that vary from one jurisdiction to another. Understanding the application of waiver in any given court, of course, is a prerequisite to later raising the issue of revival should circumstances warrant. Indeed, the seeds of revival often germinate depending on a court's view of the equity underlying the initial waiver or the abruptness of a change of legal course in a case. And, in some special situations, a court may conclude that no waiver occurred at all.

At the outset of a case, particular circumstances may delay a party's filing of a motion to compel arbitration and instead lead to a decision to participate in the ongoing litigation. Participating in litigation, however, carries the risk that the party will be found to have waived the right to later pursue arbitration for the same claim.

The choice to remain on the litigation path, which may occur once or several times in a single case, has far-reaching effects on both parties' eventual ability to access arbitration. For the party seeking it, prior participation in litigation can block the road to arbitration, notwithstanding the FAA's policy in favor of arbitration. Conversely, without clear guidance on exactly what constitutes waiver, a party resisting arbitration but actively engaged in litigation with a party seeking arbitration may lack certainty about an opponent's ultimate ability to secure arbitration. The

80. 563 U.S. 333 (2011).

81. See Carcich v. Rederi A/B Nordie, 389 F.2d 692, 696 (2d Cir. 1968) (noting that a party's inconsistent actions do not necessarily constitute prejudice for waiver purposes); see also Erdman Co. v. Phoenix Land \& Acquisition, LLC, 650 F.3d 1115, 1120 n.4 (8th Cir. 2011) (citing Carcich as the origin of the prejudice requirement). 
magnitude of these concerns varies with the jurisdiction and the facts of any given case.

Yet, these concerns are hardly academic. In 2011, a party in In re Toyota Motor Corp. Hybrid Brake Marketing, Sales, Practices \& Products Liability Litigation that failed to seek to compel arbitration, believing it was not legally available, was later found to have waived the right. ${ }^{82}$ That waiver, the district court held, prevented the defendant from later seeking arbitration through revival, even though a change in the law clarified that arbitration was possible. ${ }^{83}$ Although perhaps more of a story about revival than waiver standards, the illustration is important because had the circumstances occurred in a different jurisdiction, say the Third Circuit, ${ }^{84}$ it is unlikely that the court would have construed waiver ever to have occurred. The futility of moving to compel arbitration prior to a change in the law would have negated any waiver. And absent waiver, the right to compel arbitration would have been clear.

So understanding waiver-why, when and how it manifests-is central to an analysis of revival. Whether waiver occurs in the first instance, however, can be a complicated question. To be sure, most courts base a waiver analysis on a party's participation in litigation in a manner that is inconsistent with arbitrating a claim. ${ }^{85}$ That is, if it looks like a party pursuing litigation is acting like a party engaged in litigation, it is probably an active litigant who is not adequately preserving arbitral rights. But what looks like participation in litigation to one court may just be ancillary conduct to another. These differences underscore the reason standards for assessing waiver vary from federal circuit to circuit and from state to state. Indeed, what amounts to waiver in a federal court in East St. Louis, Illinois ${ }^{86}$ - within the Seventh Circuit where prejudice is not required $^{87}$ - may not qualify as waiver across the Mississippi River

82. 828 F. Supp. 2d 1150, 1163 (C.D. Cal. 2011) (noting that the defendant knew it could compel arbitration as a defense because it raised that right as an affirmative defense before the change in the law).

83. Id. at $1163-65$.

84. See, e.g., Chassen v. Fid. Nat'1 Fin., Inc., 836 F.3d 291, 297 (3d Cir. 2016) (“[F]utility can excuse the delayed invocation of the defense of arbitration.").

85. See generally Lilly, supra note 6, at 100-12 (noting that although circuit courts differ regarding whether demonstrating prejudice, and to what degree prejudice must be demonstrated, is a necessary condition of finding waiver, waiver is justified because litigation is inconsistent with arbitration).

86. A courthouse for the United States District Court for the Southern District of Illinois is located at 750 Missouri Avenue, East St. Louis, Illinois. United STATES DistRict COURT FOR THE SOUTHERN DISTRICT OF ILLINOIS, https://www.ilsd.uscourts.gov/Directory.aspx [https://perma.cc/XR 8P-JWTC] (last visited Oct. 9, 2018).

87. Lilly, supra note 6, at 107. 
approximately three miles away at the federal courthouse in St. Louis, Missouri ${ }^{88}$ - within the Eighth Circuit where prejudice is a component of waiver. ${ }^{89}$ A showing of prejudice to the opposing party may be required in Dallas (Fifth Circuit) ${ }^{90}$ but not in Denver (Tenth Circuit). ${ }^{91}$ No two federal appellate jurisdictions are exactly alike when addressing these issues. $^{92}$

On one end of the spectrum, the Fifth Circuit applies a "presumption against waiver," which leaves the party resisting arbitration with a "heavy burden" to show waiver. ${ }^{93}$ At the opposite end, the Seventh Circuit does not even require a showing of prejudice to the party advocating waiver. ${ }^{94}$ In between is a muddled picture of varying standards with which different courts analyze different elements of participation in litigation differently. What most evaluate in the end, however, is whether the party asserting waiver was prejudiced - and the extent to which it matters. ${ }^{95}$ But as one court explained regarding the opacity of the case law on waiver and prejudice, "A Nordic smorgasbord of United States Circuit Court of Appeals decisions greets us on the subject of prejudice for purposes of arbitration waiver." 96 Because a party's right to revival may depend on how or why waiver occurred and the extent to which prejudice is involved, understanding the implications of waiver in various jurisdictions is essential to analyzing revival.

88. A courthouse for the United States District Court for the Eastern District of Missouri is located at 111 South 10th Street, St. Louis, Missouri. United STATES District CourT FOR THE EASTERN DISTRICT OF MISSOURI, http://www.moep.uscourts.gov/division/thomas-f-eagleton-uscourthouse [https://perma.cc/SGV4-NV49] (last visited Oct. 9, 2018). Driving Directions from 750 Missouri Avenue, East St. Louis, IL to 111 South 10th Street, St. Louis, MO, Google MAPS, https://www.google.com/maps (follow "Directions" hyperlink; enter "750 Missouri Avenue, East St. Louis, Illinois" in the starting point field and "111 South 10th Street, St. Louis, Missouri" in the destination field).

89. Lilly, supra note 6 , at $106 \&$ n. 141 .

90. Id. at $103-04$.

91. Id. at $107-08$.

92. Id. at 102-11 (describing different approaches taken by different circuits).

93. Subway Equip. Leasing Corp. v. Forte, 169 F.3d 324, 326 (5th Cir. 1999); see also Keytrade USA, Inc. v. Ain Temouchent M/V, 404 F.3d 891, 897 (5th Cir. 2005) (noting the "well-settled rule in this circuit that waiver of arbitration is not a favored finding, and there is a presumption against it" (quoting Steel Warehouse Co. v. Abalone Shipping Ltd. of Nicosai, 141 F.3d 234, 238 (5th Cir. 1998))).

94. See infra notes 101-06 and accompanying text.

95. See Lilly, supra note 6, at 102-12. In his article, Professor Lilly defines four broad categories of courts vis-à-vis waiver: those that require a "heavy burden" to show prejudice; those that require a "modicum of prejudice"; those that are somewhere in between "heavy burden" and "modicum"; and those that require no prejudice at all.

96. Schuster v. Prestige Senior Mgmt., L.L.C., 376 P.3d 412, 423 (Wash. Ct. App. 2016). 


\section{A. Seventh and Fifth Circuit: The Polar (Presumption) Opposites and the Search-or Not-for Prejudice}

The lack of both a unified waiver theory and bright-line test has produced a confusing situation in which courts apply their own views regardless of positions taken by neighboring jurisdictions. No two courts appear more sharply divided, however, than the Seventh and Fifth Circuits. In the Fifth Circuit, the presumption against waiver routinely leaves parties unable to establish the required prejudice to demonstrate waiver and preclude enforcement of an agreement to arbitrate. The polar opposite of the Fifth Circuit's "presumption against waiver" is the Seventh Circuit's position that participating in litigation is "a presumptive waiver of the right to arbitrate." 97 These opposing tests reflect the divergent views that each court holds of what amounts to "waiver."

"Waiver consists of a voluntary and intentional relinquishment of a known right. $" 98$ In the contractual setting, which would include arbitration agreements, a contract "requirement cannot be suddenly revived to the prejudice of a party who has changed his position in reliance on the supposed suspension [of the waived contract term.]"99 That is, both the instance of waiver by the party choosing to participate in litigation and the detrimental reliance on that waiver by the party opposing arbitration may be assessed in determining whether waiver of the right to arbitrate occurred. ${ }^{100}$

When courts consider detrimental reliance in the arbitral waiver context, they frequently refer to it as "prejudice." 101 Most, but not all of them, require some showing of prejudice, or reliance, by the opposing party before concluding that a party seeking arbitration waived its right to do so. On the other hand, as observed below, the Seventh Circuit typifies those jurisdictions that hold prejudice is unnecessary to find waiver.

The Seventh Circuit takes a purely contractual approach to waiver, which it explains is no different than analyzing waiver of any other contract right. ${ }^{102}$ Indeed, within the footprint of the Seventh Circuit, the

\footnotetext{
97. Cabinetree of Wis., Inc. v. Kraftmaid Cabinetry, Inc., 50 F.3d 388, 390 (7th Cir. 1995).

98. Cherokee Nation v. United States, 355 F.2d 945, 950 (Ct. Cl. 1966).

99. Gresham \& Co. v. United States, 470 F.2d 542, 555 (Ct. Cl. 1972).

100. As a recent state court explained, federal courts have conflated the two concepts of waiver and reliance into a single waiver analysis. Schuster, 376 P.3d at 420-21 (noting that principles of both waiver and estoppel, or reliance, should apply but that "[f]or some unknown reason, federal courts employ only waiver when addressing unenforceability of an arbitration clause").

101. See supra note 98.

102. St. Mary's Med. Ctr. of Evansville, Inc. v. Disco Aluminum Prods. Co., 969 F.2d 585, 590 (7th Cir. 1992).
} 
FAA's policy favoring arbitration is instead "merely a policy of treating such clauses no less hospitably than other contractual provisions." 103 In that regard, parties can modify the agreements through their conduct, and choosing a non-arbitral litigation forum - by failing to move to compel arbitration at the earliest possible moment-will be deemed a waiver of the right to later pursue arbitration. ${ }^{104}$ The court explained this in its 1995 opinion Cabinetree of Wisconsin, Inc. v. Kraftmaid Cabinetry, Inc. when it held that a party who removed a case to federal court without immediately moving to compel arbitration indicated its intent to pursue litigation. ${ }^{105}$ As Judge Posner forcefully articulated in Cabinetree, "Parties know how important it is to settle on a forum at the earliest possible opportunity, and the failure of either of them to move promptly for arbitration is powerful evidence that they made their election-against arbitration." 106

Once the presumptive waiver doctrine is applied, as it is from the earliest stages of litigation in the Seventh Circuit, any search for prejudice to the party resisting arbitration is largely beside the point because the contractual nature of the dispute controls the result. ${ }^{107}$

At the other end of the waiver spectrum is the Fifth Circuit, where "prejudice ... is the essence of waiver." 108 There, decisions recite that the FAA policy favoring arbitration ${ }^{109}$ - not principles of contract law-

103. Cabinetree, 50 F.3d at 390 (citing St. Mary's Med. Ctr., 969 F.2d 585). As construed by the St. Mary's court, "the federal policy embodied in the Arbitration Act is a policy favoring enforcement of contracts, not a preference for arbitration over litigation." 969 F.2d at 590.

104. See Cabinetree, 50 F.3d at 390-91 (describing the filing of a law suit in lieu of arbitration as a "presumptive waiver"). See also Ernst \& Young LLP v. Baker O’Neal Holdings, Inc., 304 F.3d 753, 756-58 (7th Cir. 2002) (affirming waiver where party seeking arbitration lacked diligence in "mak[ing] the earliest feasible determination of whether to proceed judicially or by arbitration" (quoting Cabinetree, 50 F.3d at 391)).

105. Cabinetree, 50 F.3d at 391.

106. Id.

107. Id. at 390 ("To establish a waiver of the contractual right to arbitrate, a party need not show that it would be prejudiced if the stay were granted and arbitration ensued." (citing St. Mary's Med. Ctr., 969 F.2d 585)).

108. E. C. Ernst, Inc. v. Manhattan Constr. Co., 559 F.2d 268, 269 (5th Cir. 1977) (per curiam).

109. Federal policy favoring arbitration can be found within Section 2 of the FAA which provides that "(a) written provision in any maritime transaction or a contract evidencing a transaction involving commerce to settle by arbitration a controversy thereafter arising out of such contract ... shall be valid, irrevocable, and enforceable." 9 U.S.C. § 2 (2012). The policy was enacted in the 1925 passage of the FAA to "reverse[] an entrenched common law hostility towards arbitration." David F. Sawrie, Note, Equitable Estoppel and the Outer Boundaries of Federal Arbitration Law: The Alabama Supreme Court's Retrenchment of an Expansive Federal Policy Favoring Arbitration, 51 VAND. L. REV. 721, 723 (1998). See also Southland Corp. v. Keating, 465 U.S. 1, 10 (1984) ("In enacting § 2 of the federal Act, Congress declared a national policy favoring arbitration ...."). But see Rita M. Cain, Preemption of State Arbitration Statutes: The Exaggerated Federal Policy Favoring Arbitration, 19 J. CONTEMP. L. 1, 11-13 (1993) (arguing that the policy favoring arbitration was "strictly a 
requires a "strong presumption against finding a waiver of arbitration," 110 even when a party pursues arbitration after years of court litigation and is mere months from trial. ${ }^{111}$

Indeed, in the Fifth Circuit, "[a] party waives its right to arbitration only when participation in the litigation has been so substantial that compelling arbitration would prejudice the other party."112 This varying treatment reflects that in the Seventh Circuit, the primacy of contract trumps statute (the FAA); in the Fifth Circuit, the opposite is true.

Simply put, in the Fifth Circuit, the right to arbitrate is more than contractual, at least compared to the Seventh Circuit's understanding of "contractual." It is not enough to merely participate in litigation in the Fifth Circuit, even after engaging in extensive discovery, and thereby "waive" the contractual right to arbitrate. Routine litigation practice is unlikely to result in waiver in the Fifth Circuit where the heavy burden of proof remains with the party opposing arbitration. ${ }^{113}$ To cross the line into conduct that is "so substantial" that litigation participation prejudices the party opposing arbitration, the litigation conduct must reflect unfairness, if not deviousness. Where the Fifth Circuit has found prejudice, it tends to be manifested in the form of a party seeking more than one bite of the proverbial apple - unsuccessful pursuit of a dispositive motion followed by a motion to compel arbitration. ${ }^{114}$ In that sense, equity-not contract

judicially created policy" because Congress merely intended the FAA to enforce arbitration agreements between business entities).

110. Republic Ins. Co. v. PAICO Receivables, LLC, 383 F.3d 341, 344 (5th Cir. 2004) (citing Subway Equip. Leasing Corp. v. Forte, 169 F.3d 324, 326 (5th Cir. 1999)).

111. Elite Precision Fabricators, Inc. v. Gen. Dynamics Land Sys., Inc., No. H-14-2086, 2015 WL 9302843, at*1, *13 (S.D. Tex. Dec. 18, 2015) (holding no waiver where defendant did not move to compel until more than a year had passed, after a stay was lifted, and the defendant asserted the motion to compel arbitration in conjunction with a motion to dismiss). On the other hand, when a party first files an unsuccessful motion to dismiss and then follows that with a motion to compel arbitration, prejudice, and ultimately waiver, may be found.

112. Cargill Ferrous Int'l v. SEA PHOENIX MV, 325 F.3d 695, 700 (5th Cir. 2003).

113. Tenneco Resins, Inc. v. Davy Int'l, AG, 770 F.2d 416, 420-21 (5th Cir. 1985) ("While it is true that Davy waited almost eight months before moving that the district court proceedings be stayed pending arbitration, and, in the meantime, participated in discovery, this and other courts have allowed such actions as well as considerably more activity without finding that a party has waived a contractual right to arbitrate.").

114. See, e.g., In re Mirant Corp., 613 F.3d 584, 591 (5th Cir. 2010) ("A party cannot keep its right to demand arbitration in reserve indefinitely while it pursues a decision on the merits before the district court."). But in Pacheco v. PCM Construction Services, L.L.C., 602 F. App'x 945 (5th Cir. 2015), the Fifth Circuit considered waiver issues in the FLSA collective action context. There PCM Construction Services (PCM) had moved to compel arbitration after a thirteen-month delay. Id. at 946-47. In those thirteen months, PCM had filed two motions to dismiss and would file a third one after submitting its motion to compel arbitration, $i d$. at 947 , but the appellate court discounted those actions because they were "relatively limited" and "[o]nce a defendant has put the plaintiff on notice of its intent to demand arbitration, the plaintiff's burden of showing waiver by subsequent acts of the 
principles - determines waiver.

Most of the waiver standards articulated and refined by other courts can be traced to one of these extremes. Often, particularly at the statecourt level, judges seeking guidance can do little more than cite to the split, throw their hands up and pick a side.

\section{B. The Muddled Middle Ground of Waiver Analysis}

Between the extremes of the Seventh and Fifth Circuits, courts can largely be labeled by how closely they hew to either side. Some, such as the Fourth and the Tenth Circuits, line up closely to one of the extremes. Others occupy the large swath of middle ground where conclusions are not easily drawn.

The Fourth Circuit, for instance, aligns with the Fifth Circuit in rejecting a pure participation-in-litigation standard. ${ }^{115}$ Instead, "the dispositive question is whether the party objecting to arbitration has suffered actual prejudice."116 Even aggressive participation in litigation may not rise to the level of waiver if the claims subject to arbitration are not connected to any prejudice. ${ }^{117}$ Like the Fourth and Fifth Circuits, the Ninth Circuit will not easily arrive at a waiver conclusion- "waiver of

defendant is heavier." Id. at 948. The court discounted PCM's third motion to dismiss since it was filed after its motion to compel. Id. And its prior motions to dismiss had addressed only whether the named individual defendants were plaintiffs" "employers." Id. In addition to other considerations, those actions did not amount to waiver. Thus, regardless of context, waiver in the Fifth Circuit is a multifaceted issue not solely dependent on the passage of time or litigation conduct.

115. The Fourth Circuit uses its own terminology to address waiver issues. Relying on Section 3 of the FAA, which provides for waiver if a party "is not in default in proceeding with such arbitration," 9 U.S.C. $\S 3$ (2012), the Fourth Circuit has applied a "default" analysis where other courts have relied on waiver. Though similar to waiver, default applies when "the circumstances giving rise to a statutory default are limited and, in light of the federal policy favoring arbitration, are not to be lightly inferred." Rota-McLarty v. Santander Consumer USA, Inc., 700 F.3d 690, 702 (4th Cir. 2012) (quoting Maxum Founds., Inc. v. Salus Corp., 779 F.2d 974, 981 (4th Cir. 1985)). Although functionally the Fourth Circuit's search for prejudice in analyzing "default" rather than "waiver" is the same as other circuits, its source of the authority in the FAA rather than principles of contract law is a notable difference compared to courts such as the Seventh Circuit.

116. MicroStrategy, Inc. v. Lauricia, 268 F.3d 244, 251 (4th Cir. 2001) (quoting Fraser v. Merrill Lynch Pierce, Fenner \& Smith, Inc., 817 F.2d 250, 252 (4th Cir. 1987)).

117. Id. at 250-51, 254 (reversing the district court's finding of waiver based on "remarkably aggressive" litigation strategy where expenses incurred in litigation related primarily to state law claims rather than federal claims subject to arbitration). Indeed, the facts of the MicroStrategy case reflect such prejudice relating to the plaintiff's state law claims that Professor Lilly suggests "[t]he MicroStrategy case indicates that the Fourth Circuit may be the most difficult circuit in which to establish the required prejudice." Lilly, supra note 6, at 105. At the same time, however, the Fourth Circuit aligns closely with the Fifth Circuit in holding that where a party must respond to discovery motions and other motions in litigation, waiver prevents subsequent compelled arbitration. But see Fraser, 817 F.2d at 252 (non-discovery and discovery proceedings prejudiced plaintiff to the extent they related to arbitrable claims). 
the right to arbitration is disfavored because it is a contractual right, and thus 'any party arguing waiver of arbitration bears a heavy burden of proof.", 118

Closer to the position of the Seventh Circuit, courts within the D.C. and Tenth Circuits ${ }^{119}$ rarely require evidence of prejudice when making waiver determinations. Specifically, the Tenth Circuit rejects the Fifth Circuit's search-for-unequivocal-prejudice approach and instead applies a six-factor totality of the circumstances test that further reflects the nuances of the law of waiver. ${ }^{120}$ One of the six non-dispositive factors is "whether the delay 'affected, misled, or prejudiced' the opposing party." "121 And as discussed further in Part IV, when a party within the Tenth Circuit fails to take advantage of a change in the law permitting arbitration and nevertheless pursues litigation through trial, it may waive the right to compel arbitration despite a change in the law that otherwise would have revived a right to arbitrate claims. ${ }^{122}$

Timeliness in pursuing arbitration is also central to how the D.C. Circuit assesses waiver. There, as in the Seventh Circuit, a defendant who does not assert the contractual right to arbitrate at the first opportunity, "typically in filing his first responsive pleading or motion to dismiss, has presumptively forfeited that right." 123

The remainder of the federal courts occupy the muddled middle ground where prejudice plays a role in a totality of the circumstances test

118. Van Ness Townhouses v. Mar Indus. Corp., 862 F.2d 754, 758 (9th Cir. 1988) (quoting Fisher v. A.G. Becker Paribas Inc., 791 F.2d 691, 694 (9th Cir. 1986)).

119. The Tenth Circuit, in fact, adheres to the Seventh Circuit's contractual nature analysis of waiver in noting that "the right to arbitration, like any other contract right, can be waived." Reid Burton Constr., Inc. v. Carpenters Dist. Council of S. Colo., 614 F.2d 698, 702 (10th Cir. 1980) (quoting Cornell \& Co. v. Barber \& Ross Co., 360 F.2d 512, 513 (D.C. Cir. 1966) (per curiam)).

120. See, e.g., Reid Burton Constr., 614 F.2d at 702 ("There is no set rule as to what constitutes a waiver."). These have been referred to as "equitable principles." Id. at 701 n.6 (quoting Reid Burton Constr., Inc. v. Carpenters Dist. Council of S. Colo., 535 F.2d 598, 604 (10th Cir. 1976). See also Strong v. Davidson, 734 F. App'x 578, 580 (10th Cir. 2018) (referring to equitable principles).

121. Metz v. Merrill Lynch, Pierce, Fenner \& Smith, Inc., 39 F.3d 1482, 1489 (10th Cir. 1994) (quoting Peterson v. Shearson/Am. Express, Inc., 849 F.2d 464, 468 (10th Cir. 1988)). In this sense, the Tenth Circuit is similar to the position of the Restatement of the U.S. Law of International Commercial and Investor-State Arbitration, which states that "the Restatement regards prejudice and related fairness considerations as relevant and weighty but not indispensable to a finding that a party has waived an international arbitration agreement." RESTATEMENT OF THE U.S. LAW OF INTERNATIONAL COMMERCIAL AND INVESTOR-STATE ARBITRATION $§ 2-19 \mathrm{cmt}$. b (AM. LAW INST., Tent. Draft No. 4, 2015).

122. Id. at 1489-90 (explaining that defendant waited too long and failed to notify the district court of the change in the law clarifying the availability of arbitration).

123. Zuckerman Spaeder, LLP v. Auffenberg, 646 F.3d 919, 922 (D.C. Cir. 2011) (citing Fed. R. Civ. P. 8(c)). See also Nat'l Found. for Cancer Research v. A.G. Edwards \& Sons, Inc., 821 F.2d 772 , 777 (D.C. Cir. 1987) ("This circuit has never included prejudice as a separate and independent element of the showing necessary to demonstrate waiver of the right to arbitration."). 
to assess waiver. ${ }^{124}$ In the First Circuit, a "modicum of prejudice" will be sufficient to establish waiver. ${ }^{125}$ In others, the totality test controls, but standards are far from uniform in that different totality tests emphasize different components of waiver. ${ }^{126}$ The Third Circuit, in fact, applies a six-part test just to analyze prejudice. ${ }^{127}$ And in the Sixth Circuit, some panels have applied a prejudice standard, ${ }^{128}$ where others in older decisions have noted that waiver may occur without prejudice. ${ }^{129}$

And when prejudice is required, courts offer no concrete guidance as to the necessary elements. As Professor Lilly suggests, "Generally, the circuits that require unqualified prejudice avoid any precise statement as to what constitutes a sufficient showing, and instead list various circumstances that may be considered in assessing prejudice, such as delay, expense, attempts to relitigate issues lost in court, and the use of litigation discovery procedures." 130

In other words, the doctrine of waiver is largely defined by an absence of uniformity. Although the central question turns on whether a party's

124. The extensive discussion of prejudice at the waiver stage is significant because prejudice reappears as a component of the revival standard, albeit more as a secondary inquiry. Courts at both stages tend to view waiver and revival through an equitable lens, which can accommodate the peculiar facts and fairness considerations - i.e., the scope of prejudice - of any case.

125. Rankin v. Allstate Ins. Co., 336 F.3d 8, 12 (1st Cir. 2003) (citing Menorah Ins. Co. v. INX Reinsurance Corp., 72 F.3d 218, 221-22 (1st Cir. 1995)).

126. See, e.g., Gen. Star Nat'1 Ins. Co. v. Administratia Asigurarilor de Stat, 289 F.3d 434, 438 (6th Cir. 2002) (finding that "[a]n agreement to arbitrate may be waived by the actions of a party which are completely inconsistent with any reliance thereon" (quoting Germany v. River Terminal Ry. Co., 477 F.2d 546, 547 (6th Cir. 1973) (per curiam)); Ivax Corp. v. B. Braun of Am., Inc., 286 F.3d 1309, 1315-16 (11th Cir. 2002) ("In determining whether a party has waived its right to arbitrate ... we decide if, 'under the totality of the circumstances,' the party 'has acted inconsistently with the arbitration right,' and ... we look to see whether, by doing so, that party 'has in some way prejudiced the other party." ' (quoting S \& H Contractors, Inc. v. A.J. Taft Coal Co., 906 F.2d 1507, 1514 (11th Cir. 1990))); Rush v. Oppenheimer \& Co., 779 F.2d 885, 887 (2d Cir. 1985) ("Given this dominant federal policy favoring arbitration, waiver of the right to compel arbitration due to participation in litigation may be found only when prejudice to the other party is demonstrated."); S. Sys., Inc. v. Torrid Oven Ltd., 105 F. Supp. 2d 848, 853 (W.D. Tenn. 2000) ("In light of the Sixth Circuit's emphasis on inconsistent conduct and no mention of prejudice, this court will treat prejudice as a significant factor but not a dispositive one.").

127. See, e.g., Ehleiter v. Grapetree Shores, Inc., 482 F.3d 207, 222 (3d Cir. 2007) (citing Hoxworth v. Blinder, Robinson, \& Co., 980 F.2d 912, 926-27 (3d Cir. 1992)) (listing a six-part "nonexclusive list of factors relevant to the prejudice inquiry").

128. Johnson Assocs. Corp. v. HL Operating Corp., 680 F.3d 713, 717 (6th Cir. 2012) (noting that waiver occurs when a party takes actions that are completely inconsistent with an intent to arbitrate and by "delaying its assertion to such an extent that the opposing party incurs actual prejudice" (quoting Hurley v. Deutsche Bank Tr. Co. Ams., 610 F.3d 334, 338 (6th Cir. 2010))).

129. River Terminal Ry. Co., 477 F.2d at 547 ("An agreement to arbitrate may be waived by the actions of a party which are completely inconsistent with any reliance thereon." (citing Burton-Dixie Corp. v. Timothy McCarthy Constr. Co., 436 F.2d 405, 407-08 (5th Cir. 1971))).

130. Lilly, supra note 6, at 106-07 (footnotes omitted). 
participation in litigation is inconsistent with an intent to arbitrate, no two circuits agree precisely on how to answer that question or the extent to which prejudice should play a role. Because revival necessarily depends on the scope of waiver in the first instance - or absence of waiver if that is the scenario - the revival doctrine similarly varies by jurisdiction.

The picture of waiver is no clearer among state courts. Because state courts dealing with the question of whether waiver exists under the FAA tend to look to their federal counterparts for guidance, ${ }^{131}$ it is not surprising that the familiar divergence of standards exists. Texas courts, for instance, explicitly reject the Seventh Circuit's stance that prejudice is not necessary and instead hold that, even construing waiver in the contractual setting, the party "must take action inconsistent with its right to arbitration, and the party claiming waiver must be prejudiced."132 Like the Fourth Circuit, South Carolina courts require a demonstration of "actual prejudice" to support waiver. ${ }^{133}$ But in California, much like in the D.C. Circuit, ${ }^{134}$ prejudice does not register as a central concern because "if a contract provision is subject to arbitration and a party seeks a judicial resolution of a disagreement which falls within the scope of the arbitration agreement, that party waives its right to arbitration."135

Recently, an appellate court in the state of Washington provided one of the more detailed and thoughtful analyses of the law on waiver by surveying the federal- and state-court landscape before adopting the Third Circuit's six-factor standard to assess the extent of prejudice. ${ }^{136}$ However, the decision in Schuster v. Prestige Senior Management, L.L.C., while exhaustive in its analysis, paints a picture of national waiver standards that

131. Raymond James Fin. Servs., Inc. v. Saldukas, 896 So.2d 707, 710 (Fla. 2005) (“We agree that decisions of the federal circuit courts are persuasive precedent on this issue, but they are not binding.").

132. Hous. Lighting \& Power Co. v. City of San Antonio, 896 S.W.2d 366, 370 (Tex. App. 1995) (citing Psarianos v. Standard Marine, Ltd., 728 F. Supp. 438, 449 (E.D. Tex. 1989)). Illinois state courts have also rejected the Cabinetree holding, noting that the Seventh Circuit authority is not binding. See, e.g., Raymond James Fin. Servs., 896 So.2d at 711 (noting that prejudice is not required for waiver, and arbitration can be waived when a party "actually participat[es] in a lawsuit or tak[es] action inconsistent with that right"); LAS, Inc. v. Mini-Tankers, USA, Inc., 796 N.E.2d 633, 638 (Ill. App. Ct. 2003) (finding no waiver because "the defendant did not substantially participate in the trial court litigation to a point inconsistent with an intent to arbitrate, and the plaintiff neither claimed nor demonstrated any prejudice from the defendant's filing of its section 2-619 motion to dismiss [735 Ill. Comp. Stat. 5/2-619] prior to its assertion of its right to arbitrate").

133. Rich v. Walsh, 590 S.E.2d 506, 509-10 (S.C. Ct. App. 2003).

134. Nat'1 Found. for Cancer Research v. A.G. Edwards \& Sons, Inc., 821 F.2d 772, 777 (D.C. Cir. 1987).

135. Aviation Data, Inc. v. Am. Express Travel Related Servs. Co., 62 Cal. Rptr. 3d 396, 410 (Cal. Ct. App. 2007) (citing St. Mary's Med. Ctr. Of Evansville, Inc. v. Disco Aluminum Prods. Co., 969 F.2d 585, 589 (7th Cir. 1992)).

136. Schuster v. Prestige Senior Mgmt., L.L.C., 376 P.3d 412, 423-27 (Wash. Ct. App. 2016). 
appear to be little more than a confusing array of terms. Ultimately, the Schuster court concluded that participation in litigation for a year-and-ahalf was sufficient prejudice to establish waiver when the entity seeking arbitration could have immediately exercised that right upon commencement of the case. ${ }^{137}$

In Raymond James Financial Services, Inc. v. Saldukas, ${ }^{138}$ the Florida Supreme Court tried to cut through the maze of confusion and took a step that the U.S. Supreme Court has thus far been unable to accomplishresolving a circuit court split on waiver standards. ${ }^{139}$ Surveying the Florida lower-court landscape, the Florida high court noticed two defined bodies of case law - one that required prejudice to find waiver and one that did not. ${ }^{140}$ Prior to Saldukas, the Florida Supreme Court had merely held that "a party's contract rights may be waived by actually participating in a lawsuit or taking action inconsistent with that right" without referencing prejudice. ${ }^{141}$ Adopting the D.C. Circuit's standard and logic that the policy favoring enforcement of arbitration agreements is based upon contract principles rather than a preference for arbitration, the Saldukas court agreed that the crucial question is "whether, under the totality of the circumstances, the defaulting party has acted inconsistently with the arbitration right." 142 Thus "there is no requirement for proof of prejudice in order for there to be an effective waiver of the right to arbitrate" in Florida. ${ }^{143}$

\footnotetext{
137. Id. at 427 .

138. 896 So.2d 707 (Fla. 2005).

139. Id. at 710 (noting the United States Supreme Court has not addressed whether proof of prejudice is required for waiver under the FAA). In 2010, the Supreme Court granted a petition for a writ of certiorari to resolve the issue of whether prejudice was a necessary element of a waiver by litigation. See Citibank, N.A. v. Stok \& Assocs., 387 F. App'x 921 (11th Cir. 2010), cert. granted, 562 U.S. 1215 (2011). The question was presented as: "Under the Federal Arbitration Act . . . should a party be required to demonstrate prejudice after the opposing party waived its contractual right to arbitrate by participating in litigation, in order for such waiver to be binding and irrevocable?" Petition for Writ of Certiorari at *i, Citibank, 562 U.S. 1215 (2011) (No. 10-514). But the writ was dismissed when the case settled prior to review by the Supreme Court. 131 S. Ct. 2955 (2011).

140. 896 So.2d at 710 (noting that Florida's Second District Court of Appeal does not require a showing of prejudice to find waiver, whereas the Third District requires a showing of prejudice). Prior to the Florida Supreme Court's decision, three intermediate appeals courts did not require a prejudice showing to establish waiver while two other intermediate appeals courts required proof of prejudice. Id.

141. 896 So.2d at 711 (citing Klosters Rederi A/S v. Arison Shipping Co., 280 So.2d 678, 680 (Fla. 1973)).

142. Id. (quoting Nat'1 Found. for Cancer Research v. A.G. Edwards \& Sons, Inc., 821 F.2d 772, 774 (D.C. Cir. 1987)).

143. Id. (concluding that "the conflict among the district courts should be resolved in accord with the Second District's decision" that prejudice is not a requirement to finding waiver).
} 


\section{The Aggregate Action Context - An Uncomfortable Meeting of Waiver Principles and Rule 23}

The scope of waiver is also heavily influenced by the nature of the underlying action, particularly if a plaintiff seeks to represent a class under Federal Rule of Civil Procedure 23, an equivalent state-law analog, or bring a collective action under Section 16(b) of the FLSA. Waiver is perhaps trickiest to analyze in the class-action setting because courts must consider not only waiver doctrine but also their own jurisdictional boundaries with regard to proposed class members. After all, in the classaction setting, courts analyze not only whether a defendant waived the right to arbitrate as to the plaintiff but also as to the unnamed, absent class members. Answers to those questions may also turn on the procedural nuance of whether the case has been "certified" or approved for class treatment by the court at the time the defendant seeks to compel arbitration.

Class certification is an important milestone in any class-action case because it marks the point at which the trial court has jurisdiction over the claims of the class members. At the outset, of course, the claims of the named plaintiffs are before the court, but until the court issues an order certifying the class pursuant to Rule 23 standards, the class does not exist and claims of absent class members are outside a trial court's legal purview.

This understanding of the class-action landscape is premised upon a number of United States Supreme Court and other federal court opinions. In Smith v. Bayer Corp. ${ }^{144}$ the Court addressed who was a "party" to a case and who was bound by a court's decision:

[W]e have further held that an unnamed member of a certified class may be "considered a 'party' for the [particular] purpos[e] of appealing" an adverse judgment. But as the dissent in Devlin noted, no one in that case was "willing to advance the novel and surely erroneous argument that a nonnamed class member is a party to the class-action litigation before the class is certified." 145

Consequently, construing whether arbitration rights have been waived

144. 564 U.S. 299 (2011).

145. Id. at 313 (alterations in original) (citation omitted) (first quoting Devlin v. Scardelletti, 536 U.S. 1, 7 (2002); then quoting id. at $16 \mathrm{n} .1$ (Scalia, J., dissenting)); see also Standard Fire Ins. Co. v. Knowles, 568 U.S. 588, 593 (2013) ("[A] plaintiff who files a proposed class action cannot legally bind members of the proposed class before the class is certified." (citing Bayer Corp., 564 U.S. at 313)). 
as to putative, unnamed class members requires courts in the first instance to explore whether those putative class members are even before the court. ${ }^{146}$ For ease of reference, the discussion of the approaches below is divided between courts that found waiver in a class setting and those that did not.

\section{When Waiver Exists in a Class or Collective Action Setting}

Despite the seeming clarity, some courts find waiver to exist, even as to proposed class members' claims, depending on the waiver analysis visà-vis the named plaintiffs. A New Mexico appellate court recently affirmed waiver regarding proposed class members' claims based on the defendant's pre-certification actions despite the district court's lack of jurisdiction to compel unnamed class members to arbitrate their claims prior to certification. ${ }^{147}$ In affirming, the appeals court explained how framing the relevant question made all the difference:

But the question is not whether or when absent class members would be bound by an order compelling arbitration; the question is whether Defendants waived their right to invoke their right to arbitrate disputes with absent class members. Simply because the district court did not have jurisdiction to compel absent class members to arbitrate their claims does not mean that Defendants had no obligation to rely upon the clause before the district court granted Plaintiffs' motion to certify. ${ }^{148}$

In other words, even though moving to compel arbitration of absent class-member claims would have been impossible (because the court

146. The Third Circuit has held that prior to certification, the unnamed putative class members were not before the court until the class was certified. Rolo v. City Investing Co. Liquidating Tr., 155 F.3d 644, 659 (3d Cir. 1998), abrogation on other grounds recognized by Forbes v. Eagleson, 228 F.3d 471 (3d Cir. 2000); see also Barnes v. First Am. Title Ins. Co., 473 F. Supp. 2d 798, 801 (N.D. Ohio 2007) ("[T]he United States Supreme Court has held unnamed class members in class action suits are considered parties only in limited circumstances (i.e. for notice of dismissal and settlement by named plaintiffs and standing to appeal settlements by named class representatives, upon timely notice of objection)."). Some authorities, however, contend that putting labels on absent class members is not productive. See 1 William B. Rubenstein, NewBerg On Class Actions § 1:5 (5th ed. 2011) ("The position that absent class members occupy in class action litigation is sui generis, and attempts to analogize to conventional 'party' status are likely to fail. It is more logical for a court faced with a question concerning the rights and duties of absent class members to analyze the issue presented with reference to the goals of representative litigation ...."). But this approach does not create any meaningful tests for the waiver analysis and is disconnected from both Rule 23 and the courts' jurisdiction.

147. Tennyson v. Santa Fe Dealership Acquisition II, Inc., 364 P.3d 1273, 1279-80 (N.M. Ct. App. 2015).

148. Id. (emphasis added) (citing In re Cox Enters., Inc. Set-Top Cable Television Box Antitrust Litig., 790 F.3d 1112, 1119 (10th Cir. 2015)). 
could not have ruled within its jurisdiction), the court nevertheless held that the defendant waived the right to compel arbitration against absent class members by engaging in "nearly three years of extensive litigation, discovery," and class certification briefing. ${ }^{149}$ So the theory of extrajurisdictional waiver depends on the court separating its jurisdictional limitations from its authority over the defendant during the litigation.

Relying on that technique may be compelling for courts primarily concerned about fairness and efficiency in litigation. ${ }^{150}$ A Southern District of Florida court followed that path in 2016, pointing to concerns the years of litigation were poised to be rendered moot by a motion to compel arbitration of the claims of the absent class members. ${ }^{151}$ In denying the motion to compel arbitration for unnamed class members, the trial court noted that the defendant financial institution "chose litigation, rather than arbitration" from the outset, prompting the court and the parties to devote "enormous amounts of time and resources." costs expended in the case, the Gutierrez trial court said that "[i]f the Court now ordered arbitration for the class, all of the time and effort of the parties, counsel, this Court, and the Eleventh Circuit that has been devoted to this case will have been almost entirely wasted. The result would be gross inefficiency." "153 Rule 23 principles, the court held, were decisional guideposts that required rejection of the defendant's argument to "analyze the waiver issue in a vacuum." 154 That approach, the court held, "without

149. Id. at 1280 .

150. For instance, a California appellate court easily affirmed a finding of waiver in a class action by noting that the defendant "delayed for an astonishing 17 months after [the plaintiff] filed his complaint before it sought to enforce the arbitration agreement." Oregel v. PacPizza, LLC, 187 Cal. Rptr. 3d 436, 449, 451 (Cal. Ct. App. 2015); see also In re Cox Enters., 790 F.3d at 1119 (affirming waiver because "Cox could have asserted its right to arbitrate against Healy at any time during the course of the litigation, and that it could have asserted its right to arbitrate against the absent class members as a possible defense against class certification"). Likewise, another California appellate court recently held that regardless of the absence of jurisdiction over absent class members, a "trial court could properly consider [a defendant's] delay in seeking arbitration against [the named plaintiff] when deciding whether it had waived its right to compel arbitration against unnamed class members following certification.” Sprunk v. Prisma LLC, 222 Cal. Rptr. 3d 339, 353 (Cal. Ct. App. 2017); see also Watts v. U.S. TelePacific Corp., No. B277100, 2018 WL 2112134, at *5 (Cal. Ct. App. May 8, 2018) (finding waiver where the named plaintiffs had valid arbitration agreements because "from the onset of this litigation, TelePacific could have moved to compel arbitration. It chose not to do so, and it is now bound by that decision.... Under these circumstances, TelePacific had no reason to wait until after class certification to bring its motion to compel arbitration.").

151. In re: Checking Account Overdraft Litig., No. 1:09-MD-02036-JLK, 2016 WL 6082035 (S.D. Fla. Oct. 17, 2016), vacated sub nom. Gutierrez v. Wells Fargo Bank, NA, 889 F.3d 1230 (11th Cir. 2018)

152. Id. at $* 6$.

153. Id.

154. Id. 
considering the Bank's pre-certification attempts to win this case on the merits ... is antithetical to both the basic purpose, and to the practical realities, of class actions under Rule 23."155

In May 2018, however, the Eleventh Circuit vacated and remanded the trial court order, holding that Wells Fargo "did not act inconsistently with its arbitration rights as to the unnamed Plaintiffs" because "it would have been impossible in practice to compel arbitration against speculative plaintiffs and jurisdictionally impossible for the District Court to rule on those motions before the class was certified."156 That is, prior to class certification, the Eleventh Circuit explained "any plaintiffs beyond those named in the complaint are speculative and beyond the reach of the Court's power" with respect to enforcement or non-enforcement of arbitration agreements. ${ }^{157}$ The Eleventh Circuit went on to clarify that advance protection against waiver is not necessary in the putative classaction setting; "we have found no authority that requires a party to file a conditional arbitration motion against possible future adversaries - at a juncture in which adjudicating, much less exercising jurisdiction over, those claims is impossible - in order to avoid waiving its rights with regard to those parties." 158

In the wage-and-hour setting, the Sixth Circuit Court of Appeals applied a conduct-related approach to deny a motion to compel arbitration of hundreds of "opt-in" claims in Gunn v. NPC International, Inc. in 2015. ${ }^{159}$ Gunn involved an FLSA Section 16(b) collective action, which provides for class-like treatment similar to Rule 23 but requires individual plaintiffs to affirmatively opt into the case rather than certifying a class and fine-tuning it on Rule 23's opt-out procedure. ${ }^{160}$ Consequently, FLSA collective action members may "opt-in" at various points in time throughout the duration of a given case. Gunn was initially filed in

\footnotetext{
155. Id.

156. Gutierrez, 889 F.3d at 1237-38.

157. Id. at 1238 .

158. Id. at 1239. The Eleventh Circuit also emphasized that "the key ingredient in the waiver analysis is fair notice to the opposing party and the District Court of a party's arbitration rights and its intent to exercise them. If the court and the opposing party have such notice at an early stage in litigation, they can manage the litigation with this contingency in mind." Id. at 1236. Early in the case - before any discovery had been conducted-Wells Fargo explained "that it was not in a position to assert its arbitration rights against the unnamed Plaintiffs but wished to preserve those rights for when the matter became ripe for the Court to consider them." Id. at 1237.

159. 625 F. App'x 261 (6th Cir. 2015).

160. 29 U.S.C. § 216(b) (West, Westlaw through Pub. L. No. 115-231) ("No employee shall be a party plaintiff to any such action unless he gives his consent in writing to become such a party and such consent is filed in the court in which such action is brought."); see also supra notes 75-78 and accompanying text.
} 
January 2013, and by April 2014, more than 200 opt-in plaintiffs had filed consents to join the case, at which point the defendant employer attempted to assert the arbitration clause in the employment contracts. ${ }^{161}$ Rather than assess waiver on when each individual opt-in joined the case, the Sixth Circuit treated all of the claims the same. That is, because the claims of each opt-in plaintiff involved the same court, counsel, and underlying policies, "the effects of NPC's failure to timely raise arbitration-in unnecessary delay and expense - is effectively the same for all plaintiffs, irrespective of when they opted in."162 After all, the court went on, the advantages of collective treatment under the FLSA would "be unnecessarily and imprudently subverted if the waiver issue had to be individually assessed in relation to each plaintiff." 163 Arbitration rights were subordinate to the efficiency of aggregate litigation.

Some courts in the class- or collective-action setting tend to be reluctant to permit a defendant to raise arbitration late in the procedural history of the case when there is a sense that a defendant is trying to take advantage of or abuse the legal process. That is, "[a]n attempt to gain a strategic advantage through litigation in court before seeking to compel arbitration is a paradigm of conduct that is inconsistent with the right to arbitrate."164 A central district of California court, for instance, found waiver in 2012 when, after several years of litigating, a defendant title insurance company moved to compel arbitration of class members' claims following class certification. ${ }^{165}$ In Edwards v. First American Corp., the court acknowledged that moving to compel arbitration of the class claims would have been futile prior to class certification but castigated the defendants for never mentioning their intention to raise arbitration as a defense until after the Ninth Circuit affirmed the class certification order. ${ }^{166}$ And even then, the defendants waited an additional ten months to move to compel arbitration, prompting backlash from the court for conduct that

appear[ed] to be highly calculated-Defendants would obviously prefer that Plaintiff's claims be dismissed on the merits, as any such ruling may be used for the purposes of issue preclusion and precedential effect in subsequent actions.... Only after it appeared to Defendants that this

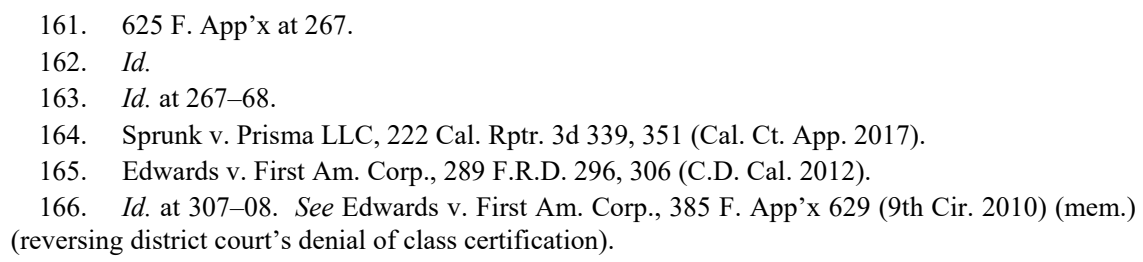


would not be possible did they file the instant motion. ${ }^{167}$

Describing such tactics as improper "gamesmanship," the court concluded the defendants waived their right to arbitrate the class claims. ${ }^{168}$

When consolidation of multiple class actions leads to multidistrict litigation, the resulting class membership may implicate waiver if some class members have arbitration agreements and others do not. The First Circuit encountered that issue in In re Citigroup, Inc. in 2004, where it held that the defendant waived its right to arbitrate the claims of class members with arbitration agreements because of its litigation conduct. ${ }^{169}$ The defendant waited too long - more than three years after the filing of the complaint and eighteen months after class certification-before moving to compel arbitration. ${ }^{170}$ Such an extended interval was "sufficient to waive Travelers's right to arbitrate, as long as the delay was prejudicial to plaintiffs." 171

Finally, in the class setting, the scope or existence of waiver can be unclear if a defendant company's officer testifies that the company does not intend to enforce arbitration provisions for a given class of litigantseven if that testimony occurs outside of the underlying case. In Mitchell v. Wells Fargo Bank, ${ }^{172}$ a federal court in Utah recently reserved judgment on whether Wells Fargo's chief executive officer effectively waived the bank's right to assert arbitration clauses in defense of a financial fraud class action regarding unauthorized customer accounts.

During the pendency of the case, Wells Fargo CEO Timothy Sloan testified before Congress and stated that "Wells Fargo is no longer utilizing forced arbitration in cases of unauthorized accounts." $"$ In deciding whether Wells Fargo waived the right to compel arbitration of sixty-five of the sixty-seven class members' claims, the court found the following testimony particularly relevant:

Senator Tester: Okay, Tim, the only time I get in fights with folks who

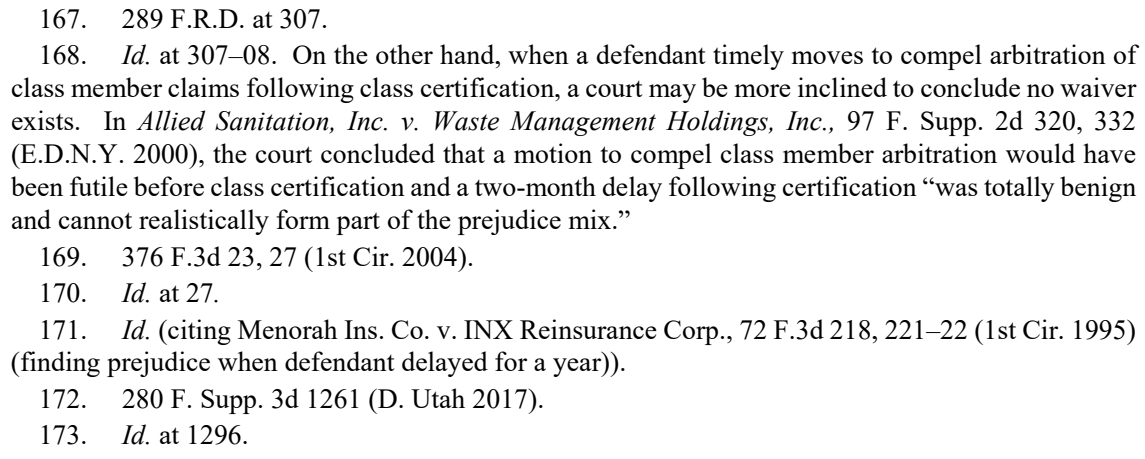

168. Id. at 307-08. On the other hand, when a defendant timely moves to compel arbitration of class member claims following class certification, a court may be more inclined to conclude no waiver exists. In Allied Sanitation, Inc. v. Waste Management Holdings, Inc., 97 F. Supp. 2d 320, 332 (E.D.N.Y. 2000), the court concluded that a motion to compel class member arbitration would have been futile before class certification and a two-month delay following certification "was totally benign and cannot realistically form part of the prejudice mix."

169. 376 F.3d 23, 27 (1st Cir. 2004).

170. Id. at 27 .

171. Id. (citing Menorah Ins. Co. v. INX Reinsurance Corp., 72 F.3d 218, 221-22 (1st Cir. 1995) (finding prejudice when defendant delayed for a year)).

172. 280 F. Supp. 3d 1261 (D. Utah 2017).

173. Id. at 1296. 
are talking is when they don't give me a yes or no answer when I really ask it, and the question is this, and you can ask it another way, answer it in another way if you want, but, uh, are you, will you commit to not use forced arbitration on accounts that were not authorized by the customer?

Timothy Sloan: The, the easy answer for that, uh, Senator, is yes, because we haven't done that.

Senator Tester: Okay.

Timothy Sloan: We're, we are not doing that.

Senator Tester: And you're not going to do it moving forward?

Timothy Sloan: We're not doing that. ${ }^{174}$

That testimony, the court held, created an issue of fact as to whether Wells Fargo waived its arbitral rights because, as the CEO, Sloan's statements could bind the corporation. ${ }^{175}$ Ultimately, the courts that find waiver in the class setting tend to do so when the circumstances of the litigation suggest that waiver would be or could be an equitable solution to a complex dilemma.

\section{When Waiver Does Not Exist in a Class or Collective Action Setting}

Not surprisingly, when courts hold that defendants did not waive the right to compel arbitration as to absent class members, those opinions emphasize jurisdictional concepts that would have rendered earlier motions pointless. ${ }^{176}$

A Northern District of California court expounded at length on these issues in 2011 when it held in an antitrust class action that defendants had not waived their right to arbitrate against "unnamed members" of the class. ${ }^{177}$ In In re TFT-LCD (Flat Panel) Antitrust Litigation, the

174. Id. See also Wells Fargo: One Year Later: Hearing Before the S. Comm. on Banking, Hous., \& Urban Affairs, 115th Cong. 12 (2017) (discussion between Timothy Sloan, CEO \& President of Wells Fargo, and Sen. Tester).

175. Id. at 1296-97.

176. See, e.g., Mora v. Harley-Davidson Credit Corp., No. 1:08-cv-01453-AWI-BAM, 2012 WL 1189769 , at *15 (E.D. Cal. Apr. 9, 2012) (holding no right to compel arbitration against unnamed, proposed class members prior to class certification). Similarly, when a plaintiff without an arbitration agreement files a class action, a defendant may not compel arbitration simply because unnamed, proposed class members have arbitration agreements. See Lee v. S. Cal. Univ. for Prof'l Studies, 56 Cal. Rptr. 3d 134, 136 (Cal. Ct. App. 2007) ("We affirm and find that no grounds exist for compelling arbitration when the only plaintiff currently before the court never agreed to arbitrate her claims.").

177. In re TFT-LCD (Flat Panel) Antitrust Litig., No. M 07-1827 SI, 2011 WL 1753784 (N.D. 
defendants had filed two motions to dismiss, opposed class certification, and participated in discovery - all without seeking arbitration against the named plaintiffs. ${ }^{178}$ But when the defendants moved to compel arbitration, they specifically excluded named plaintiffs from the scope of the motion; rather, the defendants directed the motion towards the class members who entered into arbitration agreements with one or more of the defendants but who did not exclude themselves from the class during the opt-out period following class certification. ${ }^{179}$ That made all the difference to the court in granting the motion to compel because the "defendants could [not] have moved to compel arbitration against such entities prior to the certification of a class ... because ... 'putative class members are not parties to an action prior to class certification." "180 Defendants had therefore not waived their right to arbitrate against "unnamed members" of the class. ${ }^{181}$

The jurisdictional hurdle, in fact, presents itself when defendants move to compel arbitration before a class certification ruling. As courts encountering such strategies have held, there is "no procedure or authority under [the FAA] to compel putative class members, who are not currently before the court and, because a class has not yet been certified, have not even received notice of the litigation, to arbitrate their potential claims against Defendants." "182

The same analysis applies - in some courts - in the FLSA wage-andhour context when opt-in plaintiffs have not joined the case. Recently, in Taylor v. Pilot Corp., the Middle District of Tennessee took a different approach from the Sixth Circuit in Gunn and held at the Conditional Certification stage - before any opt-in plaintiffs had filed consent forms"[d]efendants would have been unable to compel putative class members' claims to arbitration." 183 Therefore, with respect to those putative class members, the defendants did not waive the right to arbitrate their claims.

\footnotetext{
Cal. May 9, 2011).

178. Id. at $* 3$.

179. Id. at $* 4$.

180. Id. at *4 (quoting Saleh v. Titan Corp., 353 F. Supp. 2d 1087, 1091 (S.D. Cal. 2004)).

181. Id.; see also Sky Sports, Inc. v. Superior Court, 134 Cal. Rptr. 3d 405, 409-10 (Cal. Ct. App. 2011) (holding no waiver prior to class certification under California law because "had the company brought a motion to compel arbitration before class certification, the trial court would have denied the motion because [the named plaintiff] was not a party to the arbitration agreement").

182. Whittington v. Taco Bell of Am., Inc., No. 10-cv-01884-KMT-MEH, 2011 WL 1772401, *5 (D. Colo. May 10, 2011); see also Hafer v. Vanderbilt Mortg. \& Fin., Inc., 793 F. Supp. 2d 987, 1010 n.12 (S.D. Tex. 2011) ("The Court does not hereby rule on the arbitrability of the claims of putative class members. Given that no class has been certified, such a ruling would be premature." (citing Whittington, 2011 WL 1772401, at *5)).

183. Taylor v. Pilot Corp., No. 14-cv-2294-SHL-tmp, 2016 WL 4524310, at *3 (W.D. Tenn. Mar. 3, 2016), aff'd, 697 F. App'x 854 (6th Cir. 2017).
} 
In Taylor though, the defendants had raised arbitration as a defense several times, supporting the court's conclusion of an absence of waiver. ${ }^{184}$ Thus, jurisdictional concerns combined with diligence on the defendant's part in alerting the court to the arbitration issues appeared to influence the result.

\section{The Impact of the Lack of a Uniform Standard}

The patchwork of standards throughout the country leaves a waiver doctrine that largely lacks definition or explicit boundaries. The scope of whether arbitrable rights have been waived depends not just on the circumstances of a given case, but also the address of the courthouse. The inconsistency with regard to adjudication not only undermines the perceived validity of judicial decisions, but it injects inefficiency into the legal system because litigants must play a guessing game at which standards and rules ultimately will govern their dispute. And the same waiver standards should generally be applicable to both defendants and plaintiffs. ${ }^{185}$

Some uniform waiver guidelines would inject more certainty into the dispute resolution arena. For instance, it makes little sense that different federal court jurisdictions would apply different waiver tests or that class certification would matter in one circuit but not another. Either a showing of prejudice to the party opposing arbitration should be required or it should not. Of course, the individual circumstances of any given case underlying a waiver argument will differ and should be considered. But those facts should be analyzed against the same legal backdrop that uses the same test for waiver whether the court sits in Chicago, Dallas, or Fargo.

That is not to say that a fixed bright-line rule is the preferred solution. At the very least, the Tenth Circuit offers wise advice, for instance, against

184. Id. Indeed, when Pilot sought interlocutory review of the order conditionally certifying an FLSA notice class, the Sixth Circuit agreed that Pilot had not - and could not have - compelled any non-parties to arbitrate their claims. Taylor v. Pilot Corp., 697 F. App'x 854, 860 (6th Cir. 2017) ("When Pilot requested a stay, no plaintiff in the litigation had a claim — or an issue in a claimreferable to arbitration."). Moreover, the Sixth Circuit affirmed the district court's ruling that Pilot was not entitled to a stay of the proceedings pending arbitration because, up to that point, no opt-in plaintiffs with arbitration agreements had joined the case. Id. See also In re Checking Account Overdraft Litig., 780 F.3d 1031, 1037 (11th Cir. 2015) ("Absent class certification, there is no justiciable controversy between Wells Fargo and the unnamed putative class members. Furthermore, because the unnamed putative class members are not yet before the court, any claims that they might have against Wells Fargo necessarily exist only by hypothesis.").

185. See Tulip v. Serv. Corp. Int'1, No. 69306-9-I, 2014 WL 1977235 (Wash. Ct. App. Apr. 21, 2014) (holding plaintiff suing in state court under state law claim waived his right to arbitrate by participating as an opt-in plaintiff in class and collective actions in federal court asserting similar federal law claims and only asserted his right to arbitrate after dismissal of the class and collective claims). 
"adopt[ing] a bright-line rule of waiver just because a party has filed a lawsuit."186 Such a rule would result in waiver even if a party filed a complaint one day and voluntarily dismissed it the next before even executing service. ${ }^{187}$ Obviously such a result would be preposterous and would never be followed. As Judge Paul V. Gadola urged in dissent in 1991, "[i]f the mere filing of a complaint followed by immediate dismissal does not constitute submission of issues, some line drawing must be done." 188 If so, he argued, "submission of issues" in the form of "[a] trial or dispositive motion" should be the metric by which to measure waiver. ${ }^{189}$

These sorts of common-sense approaches to waiver, interestingly, invoke the analysis of the early equity-oriented cases. After all, it seems appropriate as an equitable matter that a party engaging in dispositive motion practice, without previously raising an arbitration defense, may be deemed to have waived the right to assert arbitration. And, in the classaction context, a court's jurisdictional authority to issue decisions regarding the enforcement of absent class members' arbitration agreements is a significant issue causing disagreements among the courts. That is particularly true when the perception of "gamesmanship" appears to drive courts' decision-making. ${ }^{190}$ But what constitutes gamesmanship to one judge may just be routine litigation tactics to another. Therefore, reliance on equitable considerations should come into play, if at all, only as a last resort to prevent waiver doctrine from continuing to turn on the fairness assessments of individual judges.

And while each case must be decided based on its peculiar facts, a uniform starting point for analysis would be useful. We do know that waiver can be implied from conduct and that proof of subjective intent is not required-but sometimes little else. The variety of standards that currently apply to waiver are further reflected in how courts assess revival - both in determining whether revival is even necessary, and, if so, whether it is appropriate given the factual circumstances of a particular case.

While a determination of the ultimate decision-making mechanism is difficult, it seems that some standard that has a factual basis beyond the mere filing of an answer is appropriate. The question is easier in the classaction context where principles of due process and compliance with Rule 23 offer guidance. That is, when a court lacks jurisdiction over a putative

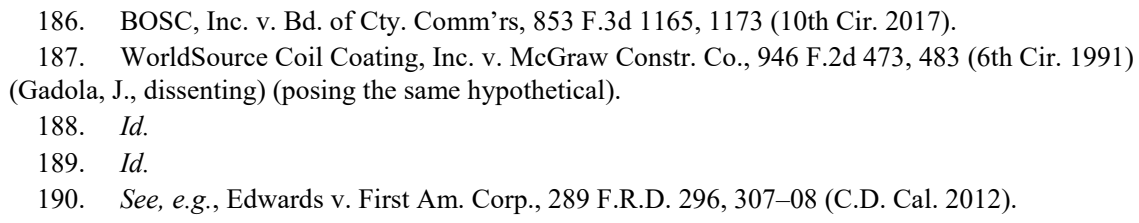


class (i.e. before class certification), then a court should not wade into the murky waters of waiver with respect to those unknown class members. No defendant, after all, has a right to compel arbitration of claims not before the court. So there is no reason to make a waiver determination prior to class certification when neither all of the parties nor their potential claims are before the court. That enhanced clarity could save significant judicial resources while preserving arbitral rights before they exist in the classaction setting.

\section{REVIVAL OF THE Right tO ARBITRATE - WHEN, How AND WHY?}

Once waiver exists, regardless of the standard applied, three concerns influence courts' decisions regarding revival of the right to arbitrate. First, the general federal policy favoring arbitration also applies where the court is considering reviving a party's arbitration rights. ${ }^{191}$

Indeed, under the Federal Rules of Civil Procedure, ${ }^{192}$ an amended complaint supplants the plaintiff's original one, and if it "changes the theory or scope of the case," 193 the defendant may plead anew as if it were responding to the original complaint. ${ }^{194}$ Courts extend this principle to cases where a party initially waived its right to arbitration but later seeks to assert it because an amended complaint reflects extensive changes.

Second, revival of a party's arbitration rights often turns on fairness concerns. So, where an amended complaint significantly alters the course of litigation, fairness requires that the party seeking arbitration receive a chance to reassert its right to compel arbitration.

In assessing fairness, courts consider the party's diligence in seeking arbitration. ${ }^{195}$ A party's deliberate delay in seeking arbitration will weigh against reviving a party's arbitration rights. This is especially true in cases where the party's delay is based on tactical considerations-for example, when a party switches from a judicial forum to an arbitral tribunal to drain the opposing party's budget.

Finally, a court is less likely to revive a party's right to arbitrate if the opposing party will be prejudiced. That is true even in jurisdictions where

\footnotetext{
191. Krinsk v. SunTrust Banks, Inc., 654 F.3d 1194, 1203 (11th Cir. 2011).

192. Fed. R. Civ. P. 15.

193. Brown v. E.F. Hutton \& Co., 610 F. Supp. 76, 78 (S.D. Fla. 1985).

194. Krinsk, 654 F.3d at 1202 (quoting Brown, 610 F. Supp. at 78); see also Brown, 610 F. Supp. at 78 (noting that if a plaintiff "chooses to redo his original work, . . . he can hardly be heard to complain that claims filed against him are improper because they should have been asserted in response to his original pleading" (quoting Joseph Bancroft \& Sons Co. v. M. Lowenstein \& Sons, Inc., 50 F.R.D. 415, 419 (D. Del. 1970))).
}

195. Cabinetree of Wis., Inc. v. Kraftmaid Cabinetry, Inc., 50 F.3d 388, 391 (7th Cir. 1995). 
prejudice is not a requirement of waiver. ${ }^{196}$ Indeed, the Seventh Circuit has provided that in revival cases, prejudice to the party resisting arbitration "should weigh heavily in the decision [of] whether to send the case to arbitration." 197

\section{A. Revival Via Amended Pleading}

To support revival by an amended pleading, generally, the amended complaint or counterclaim must reflect changes that are both significant and unanticipated. ${ }^{198}$

These components reflect global fairness considerations. Courts are concerned that the party supporting revival would have pursued a different tactic if originally presented with the amended complaint. But courts do not want to encourage parties to continuously switch forums, depleting both public and private resources.

Typically, two types of changes in an amended complaint create significant, unanticipated alterations that warrant revival of the right to compel arbitration. They concern: (1) changing the prospective class size, and (2) supplying new factual allegations or adding new claims that increase the defendant's potential liability.

\section{If an Amended Class or Collective Action Complaint Significantly Increases the Plaintiff's Class Size, a Party's Right to Compel Arbitration May be Revived.}

The stakes involved with class or collective action litigation pursuant to the Fair Labor Standards Act (FLSA) or state law create the potential for a revival situation. That is, if at first the case presented by plaintiffs does not prompt a defendant to move to compel arbitration, that strategic

\footnotetext{
196. Id.

197. Id.

198. See, e.g., Dickinson v. Heinold Sec., Inc., 661 F.2d 638, 641-42 (7th Cir. 1981) (noting the addition of arbitrable claims to a potentially non-arbitrable claim revives the right to arbitrate to all arbitrable claims despite the passage of time and discovery); Design Benefit Plans, Inc. v. Enright, 940 F. Supp. 200, 203 (N.D. Ill. 1996) ("Even if DBP's act of filing suit somehow created a presumption of waiver... the counterclaim can be seen as an 'unexpected development' which justifies granting relief from the initial waiver. ... JEI's counterclaim significantly altered the nature of this litigation and operated to rejuvenate the right to demand arbitration." (citing Cabinetree, 50 F.3d at 391, and Envirex, Inc. v. K.H. Schussler Fur Umwelttechnik GMBH, 832 F. Supp. 1293, 1296 (E.D. Wis. 1993))); Envirex, 832 F. Supp. at 1296 ("[T]he plaintiff has filed an amended complaint alleging a new basis for its fraud count, and then a second amended complaint alleging a new breach of warranty count. The defendants promptly responded to the second amended complaint with this motion [to stay in favor of arbitration].... [T] he new allegations in the amended complaints rejuvenate their right to demand arbitration.").
} 
calculus may change if and when class counsel amends a complaint to significantly expand the class. The expansion may be so significant that the original waiver becomes ineffective, causing the defendant's right to compel arbitration to be revived. In the 2011 Krinsk v. SunTrust Banks, Inc. ${ }^{199}$ opinion, for instance, the Eleventh Circuit Court of Appeals held, as a matter of first impression, that a defendant may rescind its waiver of its arbitration right upon the filing of an amended complaint that dramatically enlarges the putative class. ${ }^{200}$

In January 2010, six months after SunTrust filed a motion to dismiss, a district court granted leave for the plaintiff to amend her complaint. ${ }^{201}$ The amended complaint asserted similar claims but, most notably, proposed a new class that "greatly enlarged the potential size of the putative class," 202 expanding it from hundreds to "thousands - if not the tens of thousands" of plaintiffs. ${ }^{203}$

The Eleventh Circuit found that this case presented one of those limited circumstances where "fairness dictates that a waiver of arbitration be nullified by the filing of an amended complaint." 204 The new class definition "so altered the shape of litigation" that SunTrust was entitled to rescind its waiver despite its "prior invocations of the judicial process." 205 Under no circumstances could SunTrust have foreseen, or prepared for, Krinsk's amended complaint, which greatly expanded the putative class size to thousands, if not tens of thousands, of plaintiffs. ${ }^{206}$ So, "in plain fairness," SunTrust's prompt motion to compel arbitration should have rescinded its earlier waiver. ${ }^{207}$ The Eleventh Circuit recognized that the class size was relevant to SunTrust's original litigation strategy. For instance, if SunTrust had known that it faced a class size of thousands of plaintiffs, it might have elected to arbitrate from the beginning ${ }^{208}$ especially given that its arbitration provision precluded resolution of classaction disputes. ${ }^{209}$

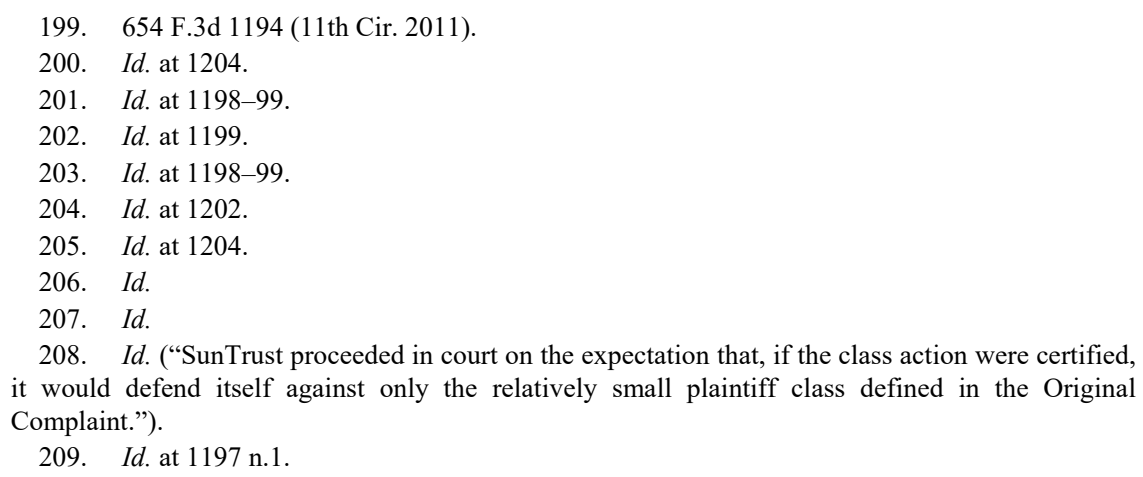


2. An Amended Complaint that Adds New Factual Allegations or Claims May Revive a Party's Right to Compel Arbitration.

Similar to a change in class size, an amended complaint that alters or enhances factual allegations may implicate revival. In Brown v. E.F. Hutton \& Co. ${ }^{210}$ a Southern District of Florida court discussed a defendant's right to a "fresh start" in answering a plaintiff's amended complaint.

Brown filed his initial complaint in 1980, on the basis of one transaction with E.F. Hutton, alleging a federal securities law violation, three counts of fraudulent misrepresentation, and a breach of fiduciary duty. ${ }^{211}$ Three years later, Brown agreed to a settlement but subsequently sought to set aside the agreement and amend his complaint, which the court allowed. ${ }^{212}$

In his amended complaint, Brown "broadened the focus of the litigation" by pleading new factual allegations. ${ }^{213}$ Specifically, Brown alleged violations on the basis of "the entire course of dealings between the parties" and not on the one transaction previously asserted. ${ }^{214}$ In addition, Brown alleged that E.F. Hutton caused \$150,000 in damages, a three-fold increase from the original complaint. ${ }^{215}$

Like the Eleventh Circuit in Krinsk, the court noted that, under the Federal Rules, when an amended complaint "changes the theory or scope of the case," the defendant is allowed to "plead anew as though it were the original complaint.",216

A change in potential liability can also present a strong case for reviving the right to arbitrate, especially where it is drastic and unforeseeable. Krinsk bolsters this position. In that case, although the change in class size motivated the Krinsk holding, the underlying issue was the defendant's increased potential liability. Litigating against hundreds of plaintiffs was financially less risky than litigating against thousands, or tens of thousands of plaintiffs.

Similarly, Plaintiffs' Shareholders Corp. v. Southern Farm Bureau Life Insurance Co ${ }^{217}$ illustrates how the addition of a new claim can affect

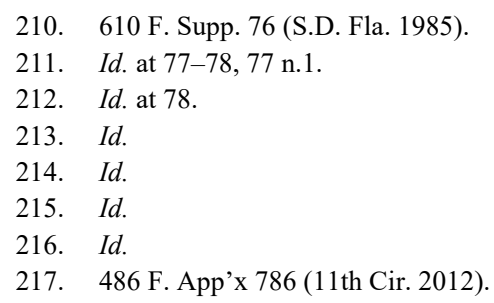


the scope of potential liability — or not—for the first time. The Eleventh Circuit took issue with the new claim in the amended complaint-the breach-of-contract allegation - in part because it gave the plaintiff access to new types of damages. ${ }^{218}$ By comparison, the other new claim in that case - the fraud-based fiduciary claim — did not differ in terms of damages from the previously asserted fraud claim. ${ }^{219}$ Thus, it appears that the court revived the right to arbitrate the former but not the latter claim.

On the other hand, the Second Circuit in Gilmore $v$. Shearson/American Express Inc. ${ }^{220}$ paid little attention to the potential escalation in damages reflected by an amended complaint. In that longrunning securities fraud case, the plaintiff Gilmore enlarged his claim of actual damages from $\$ 143,000$ to $\$ 159,000$ and punitive damages from $\$ 3,000,000$ to $\$ 10,000,000{ }^{221}$ Shearson had then attempted to revive its right to pursue arbitration, but the Second Circuit took issue with Shearson's lack of diligence in bringing the change to the lower court's attention. ${ }^{222}$ So despite the increase in potential liability, the court held that Shearson could not bring these changes as a basis for reviving its right to arbitrate on appeal for the first time. ${ }^{223}$

Litigants may also be unable to rely on amended claims that increase exposure when the heightened liability is foreseeable or implied. In Sempra Energy Resources v. California Department of Water Resources,${ }^{24}$ the original complaint only sought damages as a remedy for its breach-of-contract claim, but the amended complaint also asked for restitution and rescission of the contract. ${ }^{225}$ Viewing the original pleading as a whole, the California Court of Appeals noted that the Department sought rescission of the underlying agreement in the original complaint. ${ }^{226}$ And the court determined that, though the Department did not explicitly mention restitution in the original complaint, it was implied in the request for rescission. ${ }^{227}$ Therefore, the change did not satisfy the "unforeseeable" factor.

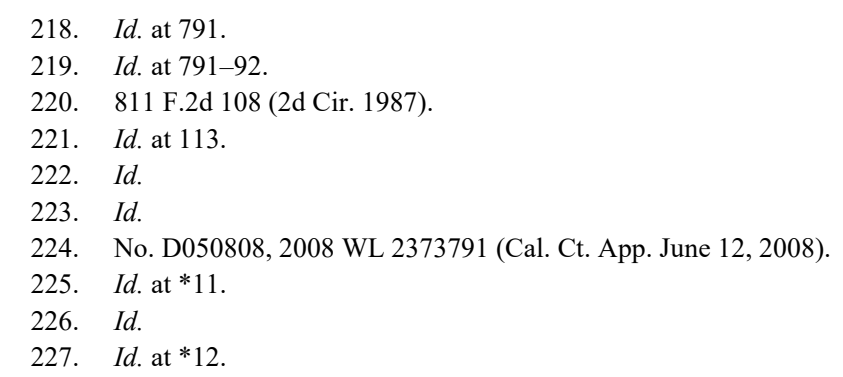




\section{B. Revival Via Change in Law: When "Futility" May Prevent Waiver Resulting From the Failure to Move to Compel Arbitration When the Existing Law Was Hostile to It}

Revival of a right to compel arbitration following waiver is commonly discussed in the context of an amended complaint that changes the stakes of litigation. But that is not the only type of circumstance where revival (or nullification of waiver) ${ }^{228}$ manifests. When a change in the relevant law transforms what previously would have been a "futile" motion to compel arbitration into a legally-cognizable motion, courts recognize a renewed right to pursue arbitration. Specifically, initial futility combined with a party's failure to make the motion does not necessarily waive a subsequently recognized right to arbitrate. ${ }^{229}$

The Gilmore v. Shearson/American Express, Inc. case, mentioned previously, presents a nuanced fact pattern and analytical approach that also illustrates the change-in-law or futility concept of revival. In Gilmore, the Second Circuit addressed revival, as a matter of first impression, in a case involving federal securities law claims and common law claims. ${ }^{230}$ Then, on remand, the Southern District Court of New York considered the issue of revival only as to a Racketeer Influenced and Corrupt Organizations Act (RICO) claim after intervening U.S. Supreme Court law clarified that the defendant's right to compel arbitration was no longer

228. Whether a right to compel arbitration is "revived" or "rejuvenated" following initial waiver or whether there was no waiver in the first place may often be a matter of semantics. Indeed, if after waiver occurs, a court holds that, in fact, the waiver is nullified and the party is free to pursue arbitration, the end result is the same as revival - a renewed right to compel arbitration. Even in jurisdictions where courts have previously relied on the concept of revival to analyze the effectiveness of a previous waiver, the discussion may still be cast in terms of nullification. The Eleventh Circuit, in fact, recently noted that the more accurate explanation for post-amendment revival was that waiver never happened in the first instance. Collado v. J. \& G. Transp., Inc., 820 F.3d 1256, 1261 (11th Cir. 2016) ("We hold that J \& G's waiver through litigation of the right to arbitrate . . does not extend to the state law claims that were pleaded for the first time after J \& G had litigated to the point of waiver [of the federal] claim."). Nevertheless, because a nullification body of case law exists, its nuances should be explored in conjunction with the revival discussion. Some courts, after all, find that an amended complaint may "nullify" the waiver of arbitration, rather than revive it. The Sempra Energy Resources v. California Department of Water Resources court was one of those courts. 2008 WL 2373791. In that case, a California appeals court considered the effect of the state Water Department's filing of an amended cross-complaint on Sempra's arbitration rights in a dispute over an energy and construction contract. Rather than exploring whether Sempra's arbitration rights were revived by an amended complaint that asserted new claims, the court examined whether the original waiver was "nullified," concluding that after six years of litigation, the waiver was not nullified by an amended complaint. Id. at *10-13.

229. Ackerberg v. Johnson, 892 F.2d 1328, 1332-33 (8th Cir. 1989) (finding no waiver when defendants failed to file a motion to compel arbitration prior to an intervening Supreme Court decision permitting the arbitration of certain securities claims).

230. Gilmore v. Shearson/Am. Express Inc., 811 F.2d 108 (2d Cir. 1987). 
futile. $^{231}$

Initially, the Second Circuit held that the "explicit waiver" of arbitration in response to an original complaint prevented a defendant from "starting fresh" in response to the amended complaint. ${ }^{232}$ The Second Circuit also relied on fairness principles in support of its position. ${ }^{233}$ The court found that, if anything, the defendant Shearson's actions during the course of litigation had been unfair to the plaintiffs. Normally, a party cannot take inconsistent positions in a lawsuit by playing "fast and loose" with the courts. ${ }^{234}$ The appellate court was particularly disturbed by Shearson's actions: Shearson's sudden withdrawal of its motion to compel arbitration was, as Gilmore opined, a "tactic in a war of attrition" so as to "make the litigation too expensive" for Gilmore, an elderly clergyman. ${ }^{235}$

Meanwhile, in 1987, the Supreme Court issued a decision holding that agreements to arbitrate RICO claims were enforceable under the FAA. ${ }^{236}$ This ruling reversed Second Circuit precedent, which until that point, held that RICO claims, such as those involved in Gilmore, were not arbitrable. ${ }^{237}$ The Supreme Court's holding in Shearson/American Express, Inc. v. McMahon thus completely altered the calculus of Shearson's right to compel arbitration upon remand. Although it had initially withdrawn its motion to compel arbitration, in large part because before McMahon, the RICO claims were not arbitrable, the McMahon decision reflected a change in the law that implicated a potential revival of Shearson's arbitration rights - even after the Second Circuit had rejected revival.

So Shearson renewed its motion to compel arbitration. ${ }^{238}$ The court for the Southern District of New York found that the "addition of the RICO claim certainly add[ed] a new theory to plaintiff's case." "239 And based on McMahon, the court found that "in fairness," it should allow Shearson to revive its right to compel arbitration on the federal securities claim. ${ }^{240}$ It

\footnotetext{
231. Gilmore v. Shearson/Am. Express Inc., 668 F. Supp. 314 (S.D.N.Y. 1987).

232. Gilmore, 811 F.2d at 112.

233. Id. at 113 .

234. Id. (quoting Selected Risks Ins. Co. v. Kobelinski, 421 F. Supp. 431, 434 (E.D. Pa. 1976)).

235. Id. Indeed, the Second Circuit relied on the magistrate's description that Shearson's original waiver of arbitration was a business decision and noted that Gilmore's litigation expenses already exceeded $\$ 217,000$ because of Shearson's extensive motion filings. Id. at $113 \&$ n.3.

236. Shearson/Am. Express, Inc. v. McMahon, 482 U.S. 220, 238-42 (1987). Interestingly, McMahon involved another case against the same defendant, Shearson, as in Gilmore.

237. See McMahon v. Shearson/Am. Express, Inc., 788 F.2d 94, 98-99 (2d Cir. 1986) (holding that RICO claims are not subject to the Federal Arbitration Act because of public policy concerns).

238. Gilmore v. Shearson/Am. Express Inc., 668 F. Supp. 314, 316 (S.D.N.Y. 1987).

239. Id. at 317 (internal quotations omitted).

240. Id. at 318 .
} 
noted that, even given Shearson's extensive discovery practice, there was no waiver in the first instance because Shearson could not have reasonably perceived the RICO claims to have been arbitrable. ${ }^{241}$

When an arbitration agreement is at least arguably enforceable, however, waiver may be appropriate even in light of a potential futility argument based on a change in law. The Eighth Circuit in Southeastern Stud \& Components, Inc. v. American Eagle Design Build Studios, LLC, ${ }^{242}$ for example, refused to permit revival in 2009 after a litigant failed to raise arbitration at the outset of a contract case where the right to assert arbitration was at least theoretically plausible before a change in the law. ${ }^{243}$ Southeastern Stud \& Components' action was filed in the Eastern District of Arkansas in June 2007, and the defendant, American Eagle Design Build Studio, LLC (AEDBS), for over a year, did not move to compel arbitration because "it did not believe it could enforce the arbitration agreement under Arkansas law." "244 At that time, "Arkansas law required mutuality of obligation within the contract's arbitration agreement, even if there was sufficient mutuality within the rest of the contract." 245

Then, after a second amended complaint, AEDBS moved to compel arbitration based on an unpublished 2008 decision by the United States District Court for the Eastern District of Arkansas. That decision clarified that "Arkansas law requiring mutuality within the arbitration paragraph itself is preempted by the [Federal Arbitration Act] because it places the arbitration clause on unequal footing with other contract terms that do not each have to be mutual."246 The district court denied the motion, holding AEDBS had waived its right to assert the arbitration provision. ${ }^{247}$

At the Eighth Circuit, AEDBS argued it did not know it had the right to arbitrate until it discovered that the Enderlin decision revived that right. Prior to the Enderlin opinion, AEDBS urged "it believed the arbitration

241. Id. at 319. Compare Kayne v. PaineWebber Inc., 684 F. Supp. 978, 982 (N.D. Ill. 1988) (granting a motion to compel arbitration as PaineWebber's inaction after the McMahon opinion was not "an unambiguous relinquishment of its contractual rights"), with Peterson v. Shearson/Am. Express, Inc., 849 F.2d 464, 467-68 (10th Cir. 1988) (holding Shearson waived its right to arbitrate state law claims, despite an intervening Supreme Court opinion clarifying the law, because the applicability of the law was not firmly established before the Court's decision and Shearson acted inconsistently in preparing for a scheduled trial).

242. 588 F.3d 963 (8th Cir. 2009).

243. Id. at $966-67$.

244. Id. at 966 .

245. Id.

246. Id. at 967 (quoting Enderlin v. XM Satellite Radio Holdings, Inc., No. 4:06-CV-0032 GTE, 2008 WL 830262, at *10 (E.D. Ark. Mar. 25, 2008)).

247. Id. at 966 . 
agreement was invalid because there was no mutuality of obligation."248 The Eighth Circuit rejected that argument because, pursuant to Supreme Court precedent clarifying the preemptive force of the FAA over contrary state law, "it should have been clear to AEDBS that the arbitration agreement was at least arguably enforceable because Arkansas could not have imposed additional requirements that applied only to arbitration agreements."249 Thus, AEDBS's attempt at revival was denied.

\section{Contemporary Approach to Futility}

Similar to the change-of-law impact in Gilmore, a significant body of case law pertaining to revival developed following the United States Supreme Court's decision in AT\&T Mobility LLC v. Concepcion. ${ }^{250}$ That doctrine is poised for rebirth as the contours of arbitrability are further refined by the Supreme Court's May 21, 2018 decision in Epic Systems Corp. v. Lewis. ${ }^{251}$

Broadly speaking, in 2011, the Supreme Court in Concepcion held that class-action waivers within arbitration provisions and subject to the FAA are enforceable. ${ }^{252}$ Specifically, Concepcion, which involved a cellular telephone contract, clarified for the first time that the FAA preempted state doctrines casting arbitration agreements as unconscionable and unenforceable in certain contexts.

Thus, before Concepcion, class-action litigants in some jurisdictions could justifiably argue that moving to compel arbitration would be futile. To the extent that they waived any right to arbitrate, Concepcion either revived that right or nullified the original waiver. ${ }^{253}$ Several courts applied such reasoning. ${ }^{254}$ used to invalidate an arbitration agreement as in violation of state public policy, because it deprives a litigant of representative litigation procedures." Paul G. Karlsgodt \& Dustin M. Dow, The Practical Approach: How the Roberts Court Has Enhanced Class Action Procedure by Strategically Carving at the Edges, 48 AKRON L. REV. 883, 894 (2015).

254. See, e.g., Swift v. Zynga Game Network, Inc., 805 F. Supp. 2d 904, 912-13 (N.D. Cal. 2011) (holding that prior to Concepcion, "a motion to compel arbitration ... would have been futile, so Zynga could not have elected to compel arbitration at the outset of this case"); see also Riensche v. Cingular Wireless LLC, Nos. C06-1325 TSZ, C09-106 TSZ, 2013 WL 951012, at *3 (W.D. Wash. Mar. 12, 2013) (same); Brown v. TrueBlue, Inc., No. 1:10-CV-0514, 2011 WL 5869773, at*6-7 (M.D. Pa. Nov. 22, 2011) (same); Kaltwasser v. AT\&T Mobility LLC, 812 F. Supp. 2d 1042, 1051 (N.D. Cal. 2011) (same); David v. Metron Servs., No. 4:10CV02052 AGF, 2011 U.S. Dist. LEXIS
} 
In 2006, for instance, the trial court in Phillips v. Sprint PCS, a consumer class action alleging misrepresentation of cellular rates, denied Sprint's motion to compel arbitration, finding the provisions requiring class action waiver unconscionable under California's consumer-friendly Discover Bank doctrine. ${ }^{255}$ Because Sprint did not appeal the decision, the case proceeded to litigation with the trial court certifying the plaintiff's class in 2008. ${ }^{256}$ Two years later, the trial court stayed the action pending the U.S. Supreme Court's resolution of Concepcion. ${ }^{257}$ And two months after Concepcion clarified that the FAA preempted California's Discover Bank rule - resulting in a major change of law-Sprint renewed its motion to compel arbitration, which the trial court granted. ${ }^{258}$ The plaintiffs then appealed, arguing that Sprint waived any right to arbitration when it failed to appeal the initial order denying the motion to compel arbitration, among other reasons. ${ }^{259}$

Ultimately, the California Court of Appeal held that Sprint did not waive its right to compel arbitration. ${ }^{260}$ The appellate court explained that although Sprint had a right to appeal, it "would have been futile given the state of law at the time."261 And the court concluded that it would not find waiver because of a party's failure to pursue a "futile" tactic. ${ }^{262}$

101652, at *8-9 (E.D. Mo. Sept. 8, 2011) (same); In re DirecTV Early Cancellation Fee Mktg. \& Sales Practices Litig., 810 F. Supp. 2d 1060, 1067 (C.D. Cal. 2011) (same), rev'd on other grounds sub nom. Lombardi v. DirecTV, Inc., 546 F. App'x 715 (9th Cir. 2013); Estrella v. Freedom Fin., No. C 09-03156 SI, 2011 WL 2633643, at*4-5 (N.D. Cal. July 5, 2011) (same); In re Cal. Title Ins. Antitrust Litig., No. 08-01341 JSW, 2011 WL 2566449, at*3 (N.D. Cal. June 27, 2011) (same). But see In re Toyota Motor Corp. Unintended Acceleration Mktg., Sales Practices, \& Prods. Liab. Litig., 838 F. Supp. 2d 967, 977-79 (C.D. Cal. 2012) (finding waiver because Toyota continued to act litigiously after Concepcion); In re Toyota Motor Corp. Hybrid Brake Mktg., Sales, Practices \& Prods. Liab. Litig., 828 F. Supp. 2d 1150, 1163 (C.D. Cal. 2011) (denying waiver when defendant asserted arbitration as an affirmative defense prior to Concepcion); Plows v. Rockwell Collins, Inc., $812 \mathrm{~F}$. Supp. 2d 1063, 1067 (C.D. Cal. 2011) (noting Concepcion invalidated the rule against class action waivers and previously defendants' counsel could reasonably have believed that the arbitration clause containing a class-action waiver in the plaintiff's agreement would have been unenforceable).

255. Phillips v. Sprint PCS, 147 Cal. Rptr. 3d 274, $277-78$ (Cal. Ct. App. 2012). The California Supreme Court held in Discover Bank v. Superior Court that, the FAA notwithstanding, consumer arbitration agreements were unconscionable under California law-and therefore unenforceablewhen the agreements were adhesive, disputes involved modest damages, and the party with less bargaining power claimed a deliberate scheme to defraud. 113 P.3d 1100,1110 (Cal. 2005), overruled by Concepcion, 563 U.S. 333 (2011).

256. Sprint PCS, 147 Cal. Rptr. 3d at 278.

257. Id. at 278 .

258. Id. at $278-79$.

259. Id. at 285 .

260. Id. at 277 .

261. Id. at 285 .

262. Id. See also Quevedo v. Macy's, Inc., 798 F. Supp. 2d 1122, 1130 n.3 (C.D. Cal. 2011) (remarking that a party need not "make all possible challenges to an existing law or risk waiving any rights it might have if that law is someday invalidated"). 
Following similar logic, the district court in Brown v. TrueBlue, Inc. ${ }^{263}$ found that the defendants had not waived their right to arbitrate. In Brown, the plaintiffs brought an action premised on Pennsylvania law and the FLSA alleging that the defendants who provided temporary staffing services gave employees the option to be paid by check or cash voucher. ${ }^{264}$ If paid by voucher, the employee would receive a voucher and a pin number which could be redeemed for cash at cash-dispensing machines located in defendants' branch offices. Employees were charged a fee for use of the machines. The plaintiffs alleged that the fees applied when using those machines often resulted in the employees receiving less than the prevailing wage. ${ }^{265}$

The plaintiffs moved for certification of two classes under Rule 23 of the Federal Rules of Civil Procedure and one collective action pursuant to the FLSA. Shortly before the hearing on class certification, defendants moved to compel arbitration. ${ }^{266}$ The court concluded that Concepcion was indeed a game changer:

[A]lthough the court is troubled that Defendants' motion to compel arbitration was not filed until fifteen months after this action commenced, it is undisputed that the reason for this delay was that Concepcion represented a significant change in the state of the law. Because this intervening change in the law of this circuit excuses Defendants' delay, and because Plaintiffs have failed to demonstrate prejudice, the court cannot find that Defendants waived their right to proceed to arbitration. ${ }^{267}$

And, while the court did not use the term "futility," it addressed the viability of filing a motion to compel before Concepcion. It concluded that defendants either risked a finding of unconscionability and a refusal to enforce the agreement or having the court require defendants to pursue class arbitration. ${ }^{268}$ "The former result would have been unsatisfactory.... The latter result, for the reasons expressed in Concepcion, would have been intolerable." ${ }^{\text {"69 }}$ What is or is not futile

\footnotetext{
263. No. 1:10-CV-0514, 2011 WL 5869773 (M.D. Pa. Nov. 22, 2011).

264. Id. at $* 1$.

265. Id.

266. Id.

267. Id. at *8.

268. Id. at *7.

269. Id. For a decision finding no waiver but using the term "futility," see In re Apple iPhone 3G \& 3GS “MMS” Mktg. \& Sales Practices Litig., 864 F. Supp. 2d 451, 457 (E.D. La. 2012) (“[P]rior to the Supreme Court's decision in Concepcion, Apple's Motion to Compel would have been futile as to the member cases transferred from districts that followed Discover Bank or an analogous rule. Courts have declined to find waiver when moving for arbitration would have been a futile act.").
} 
before a change in the law, however, may depend on the particular jurisdiction. The Eleventh Circuit came to the opposite conclusion as did many other courts in 2012 when it held that a motion to compel arbitration prior to Concepcion would not have been futile. Thus, the waiver of the right to arbitrate was not revived.

In Garcia v. Wachovia Corp.,${ }^{270}$ customers of Wells Fargo (previously Wachovia) filed class actions alleging that Wells Fargo unlawfully charged overdraft fees on their checking accounts. ${ }^{271}$ The customer agreements included an arbitration provision that allowed either party to elect arbitration but prohibited class arbitration. ${ }^{272}$ The district court twice invited Wells Fargo to move for arbitration, but it declined. ${ }^{273}$ Because neither party asserted their arbitration rights, the parties began preparing for trial. ${ }^{274}$

However, in 2011, after Concepcion, Wells Fargo moved to compel its right to arbitrate. ${ }^{275}$ Wells Fargo argued that, before Concepcion, it would have been futile to pursue its arbitration rights because state law prevented enforcement of class action waivers in customer agreements. ${ }^{276}$ The district court denied the motion premised on waiver. ${ }^{277}$

The Eleventh Circuit agreed. It found that Wells Fargo had acted inconsistently with its arbitration right when it failed to elect arbitration in response to the district court's invitation and participated in extensive discovery. ${ }^{278}$ In addition, the appellate court determined that the plaintiffs would suffer prejudice because, first, they had expended extensive sums in pursuing litigation, and, second, "Wells Fargo benefited from conducting discovery of the [class] plaintiffs.",279

The Eleventh Circuit also concluded that filing a motion to compel arbitration before the Supreme Court's Concepcion decision was not futile. ${ }^{280}$ The court noted that, absent controlling Supreme Court or circuit precedent foreclosing a right to arbitrate, a motion to compel will almost never be considered futile. ${ }^{281}$ A motion that is merely "unlikely to

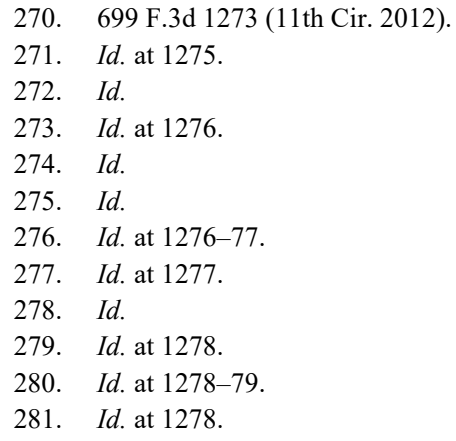


succeed" is not futile, but rather only when it is "almost certain" to fail. ${ }^{282}$

2. The Next Frontier of "Revival"?

The application of revival of the right to arbitrate in the futility context may be further defined following the Supreme Court's May 2018 decision in three consolidated cases. ${ }^{283}$ In Epic Systems Corp. v. Lewis, the Court analyzed whether arbitration agreements with class and collective waivers are enforceable under the FAA, irrespective of the National Labor Relations Board's interpretation that such agreements violate employee rights under the National Labor Relations Act (NLRA). ${ }^{284}$

In May 2016, the Seventh Circuit created a circuit split with its decision in Lewis v. Epic Systems Corp. ${ }^{285}$ which held that an arbitration agreement precluding collective arbitration or collective action violates Section 7 of the National Labor Relations Act $^{286}$ and is unenforceable under the FAA. ${ }^{287}$ That put the Seventh Circuit squarely at odds with the Fifth, Second, Eighth and Eleventh Circuits which had previously held that the FAA's policy of favoring arbitration overrides any concerted activity rights employees have to class or collective remedies. ${ }^{288}$ Subsequently, the Ninth Circuit joined the Seventh Circuit and held in Morris v. Ernst \& Young, $L L P^{289}$ that despite the FAA, under Section 7, employees have substantive rights to pursue collective relief that cannot be waived in an arbitration agreement. Meanwhile, the NLRB sought certiorari in the Fifth Circuit's holding in Murphy Oil USA, Inc. v. NLRB that Section 7 rights did not override the FAA's arbitration enforcement command. ${ }^{290}$

In January 2017, the Court granted certiorari in all three cases and consolidated them to review the scope of its Concepcion holding. ${ }^{291}$

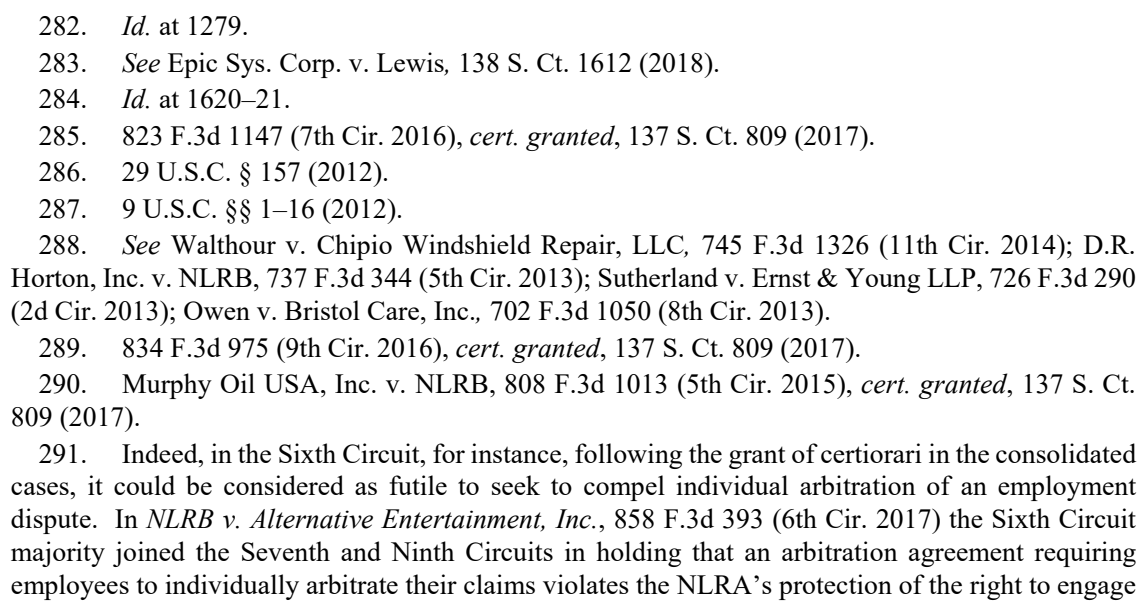

291. Indeed, in the Sixth Circuit, for instance, following the grant of certiorari in the consolidated cases, it could be considered as futile to seek to compel individual arbitration of an employment dispute. In NLRB v. Alternative Entertainment, Inc., 858 F.3d 393 (6th Cir. 2017) the Sixth Circuit majority joined the Seventh and Ninth Circuits in holding that an arbitration agreement requiring employees to individually arbitrate their claims violates the NLRA's protection of the right to engage 
Writing for a 5-4 majority, Justice Gorsuch concluded that the NLRA does not contain a class action right that trumps the FAA:

The NLRA secures to employees rights to organize unions and bargain collectively, but it says nothing about how judges and arbitrators must try legal disputes that leave the workplace and enter the courtroom or arbitral forum. This Court has never read a right to class actions into the NLRA - and for three quarters of a century neither did the National Labor Relations Board. Far from conflicting, the Arbitration Act and the NLRA have long enjoyed separate spheres of influence and neither permits this Court to declare the parties' agreements unlawful. ${ }^{292}$

Additionally, Justice Gorsuch rejected the employees' argument that the NLRA contained a congressional command to displace the FAA insofar as it concerned individual employment arbitration agreements. Section 7, however, "does not express approval or disapproval of arbitration. It does not mention class or collective action procedures. It does not even hint at a wish to displace the Arbitration Act-let alone accomplish that much clearly and manifestly, as our precedents demand." 293

Fundamentally, the majority opinion in Epic Systems was correct. Congress did not establish a right to bring collective or class legal claims within the NLRA in 1935. And no interpretations by the contemporary National Labor Relations Board changed that. Eventually, Congress did provide a procedural path to collective actions with the 1938 passage of the Fair Labor Standards Act and its 1947 amendments, which were necessary because such rights did not previously exist. All of this was clarified in Epic Systems, which sorted out the confusion presented by the consolidated cases.

Following Epic Systems, the question arises particularly in the Sixth, Seventh and Ninth Circuits as to whether employers, during the pendency of Epic Systems, waived their ability to compel arbitration when they did not do so originally. Courts within those circuits may be forced to confront anew the futility of previously seeking arbitration, affixing new gloss on the varying standards for determining "futility" so as to permit arbitration based on a change of law.

Moreover, because of the differing approaches to waiver throughout the country, a detailed analysis would still be necessary in any given case regarding whether a right to arbitrate was truly waived in the first place.

in concerted activity, which includes a guaranteed right to pursue collective action.

292. Epic Sys. Corp. v. Lewis, 138 S. Ct. 1612, 1619 (2018).

293. Id. at 1624 . 


\section{CONCLUSION}

When does a party waive its right to compel arbitration? And how does the presence - or lack thereof - of unnamed putative class members in a class action impact the waiver analysis? As this article has shown, finding the answers to those questions requires navigating a labyrinth of legal tests that differ from one jurisdiction to the next. And the historic basis of waiver or "default" adds few analytical tools. The lack of uniformity injects uncertainty into the legal system regardless of the type of claim. All sectors of litigation, from employment to products liability to antitrust to financial services, are ill-served by the differing rules that apply in different courthouses.

The same confusion persists when courts try to analyze whether a party's right to arbitrate - once waived - has been revived. Just as with the initial waiver analysis, this inconsistency is particularly problematic in the class action context where significant cost and risk are routinely at stake.

Uniformity is long overdue. Namely in the class and aggregate litigation arena, consistent approaches to waiver would help litigants understand courts' authority and jurisdiction regarding absent class member rights as well as the impact of litigation strategies designed to raise arbitration defenses at the class certification stage-but not before. Clear rules on revival would also inject greater fairness into the legal system. To be sure, however, class-action litigants should not be forced into a waiver dilemma involving theoretical claims of class members not yet before the court. In the interest of clarity and fairness, prior to class certification, there should be no need for a waiver analysis to occur with respect to putative class members. That is, if it is not ripe for a defendant to move to compel arbitration because a putative class member is not yet before the court, then the same logic should apply to waiver: it is not ripe to make a waiver determination before an absent class member is in the case through the certification mechanism.

A call for uniformity is not to say that the waiver analysis should always be the same. The facts of a particular case often do - and shouldcontrol. But the rules that govern waiver and revival of arbitration rights should not be so inconsistent and forum-dependent. Greater, if not total, clarity would be a welcome development and aid not only the parties but also the courts called upon to decide these issues. Indeed, more than a judge's reaction to a parties' litigation-related conduct in a particular case is needed. Instead, uniform standards that directly relate to the court's jurisdiction, pleading requirements or to the procedural rules relating to aggregate litigation would greatly enhance the process. 